Prepared in cooperation with the Bureau of Reclamation

\title{
Discharge and Dissolved-Solids Characteristics of Blacks Fork above Smiths Fork, Wyoming, April 2018 through September 2019
}

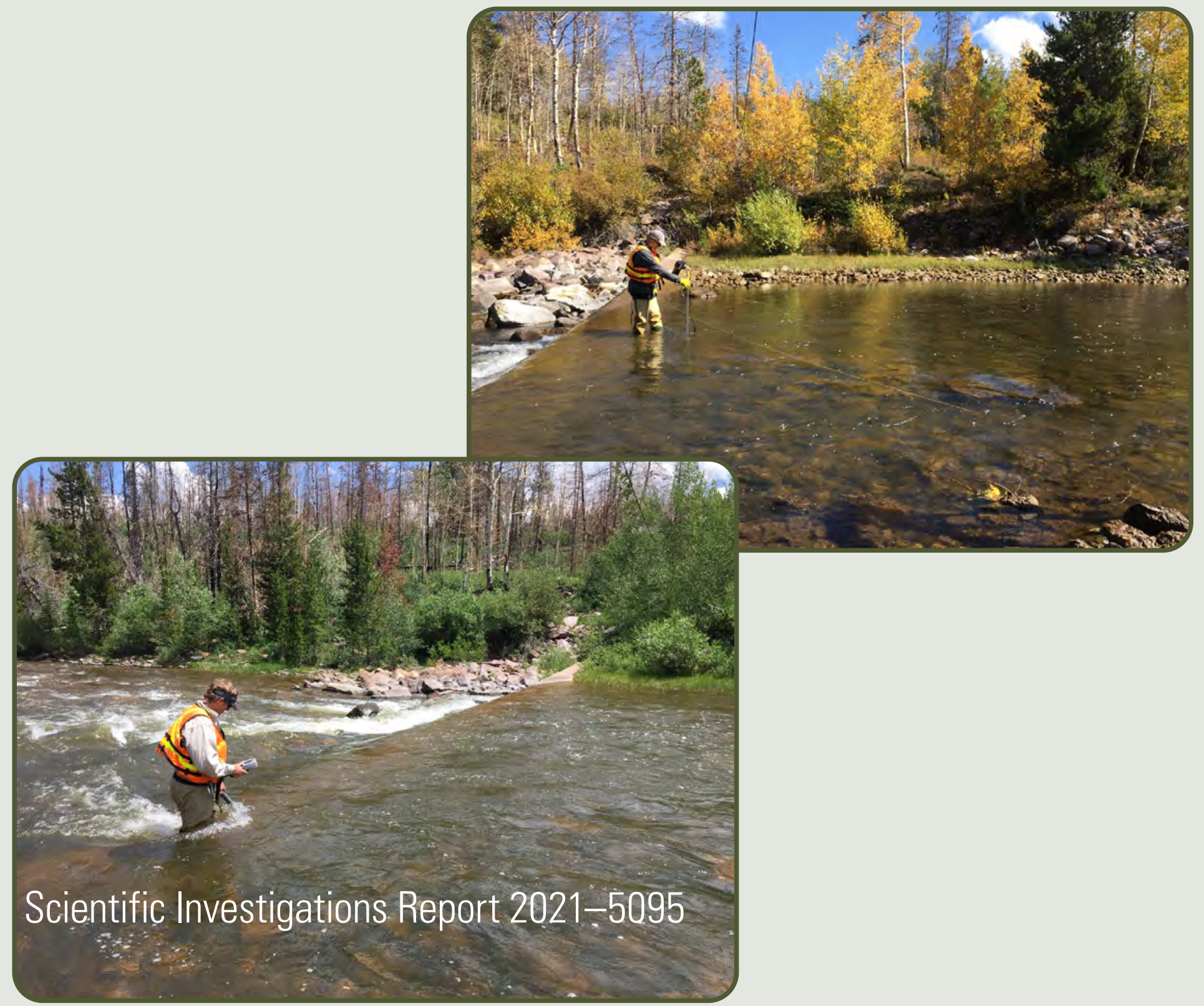

U.S. Department of the Interior U.S. Geological Survey 


\section{Front cover:}

Top, Photograph showing a hydrologist making a discharge measurement at Blacks Fork near Millburne, Wyoming, streamgage taken on October 2, 2019.

Bottom, Photograph showing a hydrologist collecting field parameters at Blacks Fork near Millburne, Wyoming, streamgage taken on July 10, 2018.

\section{Back cover:}

Photograph showing sunset over the Blacks Fork above Smiths Fork near Lyman, Wyoming, streamgage taken on October 3, 2019. 


\section{Discharge and Dissolved-Solids Characteristics of Blacks Fork above Smiths Fork, Wyoming, April 2018 through September 2019}

By Cheryl A. Eddy-Miller, Jerrod D. Wheeler, Ruth M. Law, and Shaun W. Moran

Prepared in cooperation with the Bureau of Reclamation

Scientific Investigations Report 2021-5095 


\section{U.S. Geological Survey, Reston, Virginia: 2021}

For more information on the USGS - the Federal source for science about the Earth, its natural and living resources, natural hazards, and the environment—visit https://www.usgs.gov or call 1-888-ASK-USGS.

For an overview of USGS information products, including maps, imagery, and publications, visit https://store.usgs.gov/.

Any use of trade, firm, or product names is for descriptive purposes only and does not imply endorsement by the U.S. Government.

Although this information product, for the most part, is in the public domain, it also may contain copyrighted materials as noted in the text. Permission to reproduce copyrighted items must be secured from the copyright owner.

Suggested citation:

Eddy-Miller, C.A., Wheeler, J.D., Law, R.M., and Moran, S.W., 2021, Discharge and dissolved-solids characteristics of Blacks Fork above Smiths Fork, Wyoming, April 2018 through September 2019: U.S. Geological Survey Scientific Investigations Report 2021-5095, 32 p., https://doi.org/10.3133/sir20215095.

ISSN 2328-0328 (online) 


\section{Acknowledgments}

The authors gratefully acknowledge staff and board members from the Uinta County Conservation District and Austin and Wall Irrigation District, Wyoming Water Development

Office, and Sunrise Engineering for providing background on previous work in the area and assistance with site selection.

Thanks are extended to the U.S. Geological Survey colleagues Nolan Friday, Thomas Pointon, Megan Moss, and Brittanny Brasfield for collecting data used in this report, and to Rodney Caldwell and Olivia Miller for providing reviews of the manuscript. 



\section{Contents}

Acknowledgments ……...................................................................................................................

Abstract

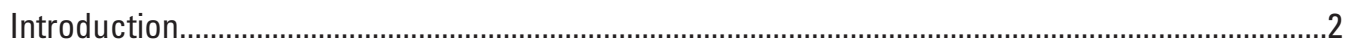

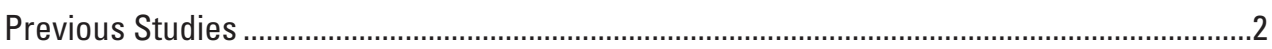

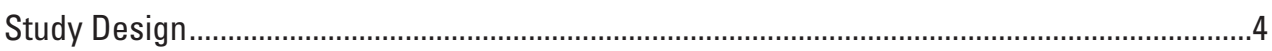

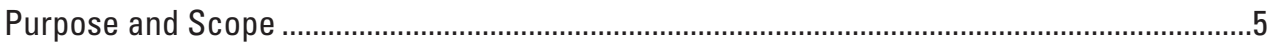

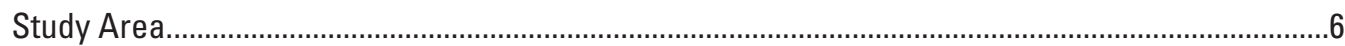

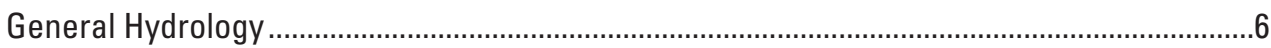

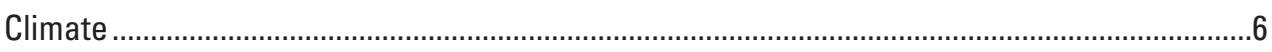

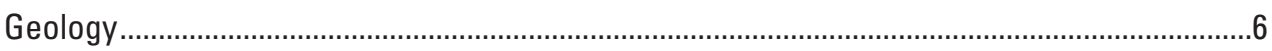

Methods

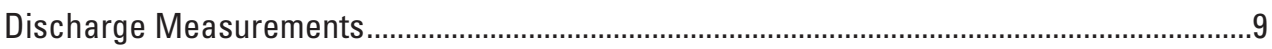

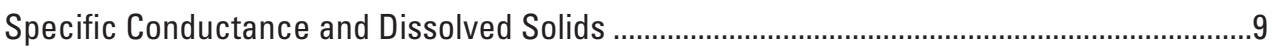

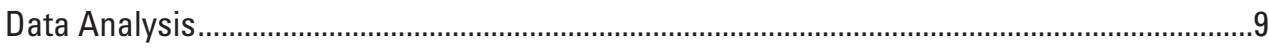

Discharge, Specific Conductance, and Dissolved-Solids Characteristics at the Blacks Fork above Smiths Fork, near Lyman, Wyoming, Streamgage ...........................................10

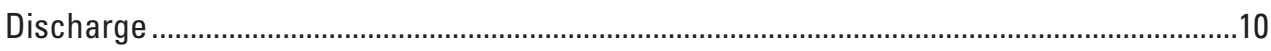

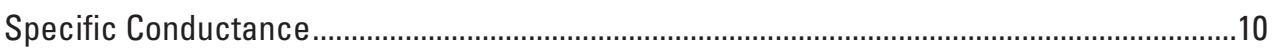

Dissolved-Solids Concentrations ........................................................................................ 10

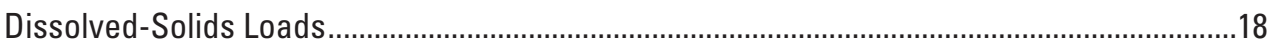

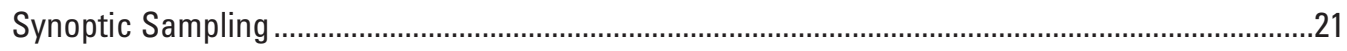

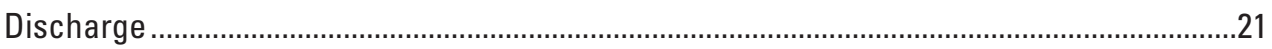

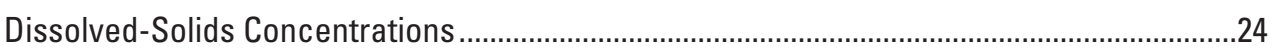

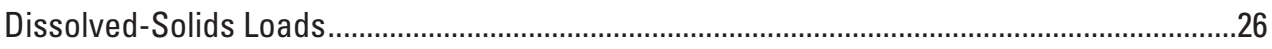

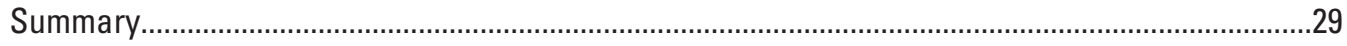

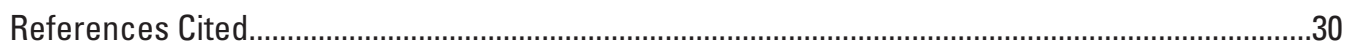

Appendix 1. Calculation of Relative Percent Differences in Dissolved-Solids

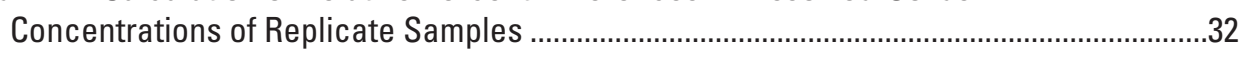

\section{Figures}

1. Map showing location and drainage basin of the Blacks Fork above Smiths Fork, near Lyman, Wyoming, streamgage and continuous specific conductance monitor, synoptic sampling sites, and area streamgages .

2. Map showing surficial deposits and bedrock units within and near the Blacks Fork drainage basin, above the confluence with Smiths Fork, southwestern Wyoming.

3. Graphs showing daily mean discharge, daily mean specific conductance, daily mean dissolved-solids concentration, and daily mean dissolved-solids load at the Blacks Fork above Smiths Fork, near Lyman, Wyoming, streamgage, April 5, 2018, through September 30, 2019.

4. Box plots showing distribution of daily mean values for the Blacks Fork above Smiths Fork, near Lyman, Wyoming, streamgage, April through September 2018 and April through September 2019 
5. Graph showing monthly discharge at four Blacks Fork streamgages during April through September 2018 and April through September 2019

6. Graph showing linear regression between specific conductance and dissolved solids calculated using samples collected during April 4, 2018, through October 2, 2019, at the Blacks Fork above Smiths Fork, near Lyman, Wyoming, streamgage

7. Graph showing relation between daily mean discharge and daily mean dissolved-solids concentration at the Blacks Fork above Smiths Fork, near Lyman, Wyoming, streamgage, April 5, 2018, through September 30, 2019

8. Schematic of synoptic sampling sites on Blacks Fork and Threemile Creek, sampled during July, August, and September 2018 and June, July, August, and September 2019......

9. Graph showing daily mean discharge at the Blacks Fork near Millburne, Wyoming, and Blacks Fork above Smiths Fork, near Lyman, Wyoming, streamgage and instantaneous discharge measurements during 2018 and 2019 synoptic sampling.

10. Box plots showing results from instantaneous samples collected on the Blacks Fork and Threemile Creek sites during the three synoptic sampling events in 2018 and the four synoptic events in 2019 ...

11. Graphs showing discharge at main-stem Blacks Fork and tributary Threemile Creek sites during seven synoptic sampling events...

12. Graphs showing dissolved-solids concentrations of samples collected from main-stem Blacks Fork and tributary Threemile Creek sites during seven synoptic sampling events

13. Dissolved-solids loads at main-stem Blacks Fork and tributary Threemile Creek sites during seven synoptic sampling events

\section{Tables}

1. Discharge and dissolved-solids synoptic sampling sites (including streamgages) used to study Blacks Fork above Smiths Fork, April 2018 through September 2019.

2. Drainage basin area and cumulative discharge for Blacks Fork streamgages during the 6-month period from April through September 2018 and April through September 2019

3. Daily mean dissolved-solids concentration; mean, minimum, and maximum of daily mean dissolved-solids concentration for each month during April 5, 2018, through September 30, 2019, Blacks Fork above Smiths Fork, near Lyman, Wyoming, streamgage.

4. Daily mean dissolved-solids load; mean, minimum, and maximum of daily mean dissolved-solids load for each month; and total monthly load during April 5, 2018, through September 30, 2019, Blacks Fork above Smiths Fork, near Lyman, Wyoming, streamgage.

5. Discharge, specific conductance, dissolved-solids concentration, and dissolved-solids load from samples collected from synoptic sampling sites on Blacks Fork and Threemile Creek, sampled during July, August, and September 2018 and June, July, August, and September 2019. 


\section{Conversion Factors}

U.S. customary units to International System of Units

\begin{tabular}{|c|c|c|}
\hline Multiply & By & To obtain \\
\hline \multicolumn{3}{|c|}{ Length } \\
\hline inch (in.) & 2.54 & centimeter $(\mathrm{cm})$ \\
\hline foot $(\mathrm{ft})$ & 0.3048 & meter $(\mathrm{m})$ \\
\hline mile (mi) & 1.609 & kilometer $(\mathrm{km})$ \\
\hline \multicolumn{3}{|c|}{ Area } \\
\hline acre & 0.004047 & square kilometer $\left(\mathrm{km}^{2}\right)$ \\
\hline square mile $\left(\mathrm{mi}^{2}\right)$ & 2.590 & square kilometer $\left(\mathrm{km}^{2}\right)$ \\
\hline \multicolumn{3}{|c|}{ Volume } \\
\hline acre-foot (acre-ft) & 1,233 & cubic meter $\left(\mathrm{m}^{3}\right)$ \\
\hline \multicolumn{3}{|c|}{ Flow rate } \\
\hline cubic foot per second $\left(\mathrm{ft}^{3} / \mathrm{s}\right)$ & 0.0283165 & cubic meters per second $\left(\mathrm{m}^{3} / \mathrm{s}\right)$ \\
\hline \multicolumn{3}{|c|}{ Mass } \\
\hline ton & 0.9072 & metric ton (mton) \\
\hline ton per day (ton/d) & 0.9072 & metric ton per day (mton/d) \\
\hline
\end{tabular}

Temperature in degrees Fahrenheit $\left({ }^{\circ} \mathrm{F}\right)$ may be converted to degrees Celsius $\left({ }^{\circ} \mathrm{C}\right)$ as follows: ${ }^{\circ} \mathrm{C}$ $=\left({ }^{\circ} \mathrm{F}-32\right) / 1.8$.

\section{Datum}

Vertical coordinate information is referenced to the National Geodetic Vertical Datum of 1929 (NGVD 29).

Horizontal coordinate information is referenced to the North American Datum of 1983 (NAD 83).

Elevation, as used in this report, refers to distance above the vertical datum.

\section{Supplemental Information}

Specific conductance is given in microsiemens per centimeter at 25 degrees Celsius $(\mu \mathrm{S} / \mathrm{cm}$ at $\left.25^{\circ} \mathrm{C}\right)$.

Concentrations of chemical constituents in water are given in milligrams per liter (mg/L).

A water year is the 12-month period from 0ctober 1 through September 30 and designated by the calendar year for which it ends (water year 2018 is the period beginning October 1, 2017, and ending September 30, 2018).

\section{Abbreviations}

USGS U.S. Geological Survey 



\title{
Discharge and Dissolved-Solids Characteristics of Blacks Fork above Smiths Fork, Wyoming, April 2018 through September 2019
}

\author{
By Cheryl A. Eddy-Miller, Jerrod D. Wheeler, Ruth M. Law, and Shaun W. Moran
}

\section{Abstract}

The Colorado River Basin Salinity Control Forum was formed in 1973 to coordinate salinity control efforts among the States in the Colorado River Basin, including Wyoming. The Colorado River Salinity Control Act of 1974 (Public Law 93-320) authorized "the construction, operation, and maintenance of certain works in the Colorado River Basin to control the salinity of water delivered to users in the United States and Mexico." Water-quality standards for salinity in the lower Colorado River Basin were adopted in 1975. To help meet these standards, the Bureau of Reclamation, Natural Resource Conservation Service, and States within the Colorado River Basin have implemented salinity control projects that focus on reducing salt loading associated with irrigated agriculture by improving water delivery systems and water management practices. The term salinity is synonymous with dissolved solids in this report.

The Bureau of Reclamation, in conjunction with the Colorado River Basin Salinity Control Forum, was interested in determining the contribution of dissolved solids from Blacks Fork above Smiths Fork to the Colorado River and initiated a study of Blacks Fork above Smiths Fork in 2018. In early 2018, the U.S. Geological Survey installed a streamgage at the most downstream location on the Blacks Fork, upstream from the convergence with Smiths Fork, to characterize the stream. The Blacks Fork above Smiths Fork, near Lyman, Wyoming, streamgage (U.S. Geological Survey identifier 09219200) was operated from April 4, 2018, through September 30,2019, collecting continuous stream stage and specific-conductance data, from which continuous discharge, dissolved-solids concentrations, and dissolved-solids loads were calculated. Seven sites were selected on Blacks Fork and a tributary to describe a snapshot of the discharge and dissolved-solids characteristics. These sites were sampled during July, August, and September 2018 and June, July, August, and September 2019.

Discharge at the Blacks Fork above Smiths Fork, near Lyman, Wyo., streamgage (09219200) from April through September in 2018 was lower and less variable than during the same period in 2019. The mean daily (mean of the daily means) discharge during those 6 months in 2018 (15.1 cubic feet per second $\left[\mathrm{ft}^{3} / \mathrm{s}\right]$ ) was about one-tenth of the discharge during the same period in $2019\left(152 \mathrm{ft}^{3} / \mathrm{s}\right)$. The cumulative monthly discharge during April through September in 2018 was 5,360 acre-feet, about one-tenth of the discharge during the same period in 2019 which was 54,700 acre-feet. Similar differences in discharge between the 2018 and 2019 periods also are noted at other Blacks Fork streamgages in the area.

Continuous specific conductance data and the statistical relation between specific conductance and dissolvedsolids concentrations were used to calculate the daily mean dissolved-solids concentrations. Dissolved solids often have an inverse relation with discharge because higher discharges typically have a diluting effect that lowers the dissolvedsolids concentrations. In general, when discharges at the Blacks Fork above Smiths Fork streamgage (09219200) are higher, dissolved-solids concentrations are generally lower. However, the high dissolved-solids concentrations that are measured during high discharges indicate that the system has natural variability and the dissolved-solids concentrations are determined by more factors than just discharge. The mean daily dissolved-solids concentration during April through September 2018 was 1,630 milligrams per liter and during the same period in 2019 was 1,100 milligrams per liter.

Dissolved-solids loads were calculated as the product of the discharge and dissolved-solids concentration. The daily mean dissolved-solids loads during 2018 were typically lower than during 2019. This result is primarily because the discharge was much lower in 2018 than in 2019. Therefore, although the daily mean dissolved-solids concentrations tended to be higher in 2018, the substantially higher discharges in 2019 had more of an effect on the dissolved-solids loads than the dissolved-solids concentrations.

The cumulative dissolved-solids load at the Blacks Fork above Smiths Fork, near Lyman, Wyo., streamgage (09219200) during the 18-month study was 81,200 tons, with a mean daily load of 149 tons per day. During the 6-month period from April through September 2018, the cumulative dissolved-solids load at the streamgage was estimated to be 8,740 tons and, during the same 6 months in 2019, 
the cumulative dissolved-solids load was estimated to be 60,900 tons. During the fall and winter between the two periods, the cumulative dissolved-solids load was 11,600 tons.

Discharge and dissolved-solids concentrations from samples collected during the synoptic sampling events were highly variable among most sites during most synoptic sampling events and also highly variable at most sites among different sampling events. The two sites upstream from the tributary input from Threemile Creek had lower dissolved-solids concentrations than sites including and downstream from the tributary. Sites including and downstream from the tributary had similar values and variability of dissolved-solids loads, with the exception of the farthest downstream site at the Blacks Fork above Smiths Fork, near Lyman, Wyo., streamgage (09219200) that tended to have larger dissolved-solids loads and higher variability among synoptic sampling events.

\section{Introduction}

The Colorado River Basin Salinity Control Forum was formed in 1973 to coordinate salinity control efforts among the States in the Colorado River Basin (not shown), including Wyoming (fig. 1) (Colorado River Basin Salinity Control Forum, 2011). The Colorado River Salinity Control Act of 1974 (Public Law 93-320) authorized "the construction, operation, and maintenance of certain works in the Colorado River Basin to control the salinity of water delivered to users in the United States and Mexico." Water-quality standards for salinity in the lower Colorado River Basin were adopted in 1975 (Colorado River Basin Salinity Control Forum, 1975). To help meet these standards, the Bureau of Reclamation, Natural Resource Conservation Service, and States within the Colorado River Basin have implemented salinity control projects that focus on reducing salt loading associated with irrigated agriculture by improving water delivery systems and water management practices (Colorado River Basin Salinity Control Forum, 2011). The term salinity is synonymous with dissolved solids in this report.

Irrigated agriculture is the largest user of water in the Colorado River Basin and a major contributor of dissolved solids to the river system. Irrigation can increase the dissolved-solids concentrations (or salinity) in downstream waters by several processes. One process is evaporation and transpiration of water applied to the crops, which removes low salinity water to the atmosphere, thereby concentrating the dissolved solids in the remaining water that returns to the stream. Another process that increases a stream's dissolved-solids concentration is by dissolving minerals from the soils and surficial rocks as the irrigation water infiltrates past the root zone and returns to the stream from groundwater. Streams may also have increased dissolved solids when rainfall or irrigation water travels overland and dissolves minerals from the soils as it moves downstream to the receiving the water. All of these processes can increase the rate in which the minerals that lead to increased salinity enter into the stream.

Blacks Fork is a stream in the Colorado River Basin; its flow originates from snowmelt in the mountains of southwestern Wyoming and northeastern Utah. Blacks Fork then flows for about 150 miles through the semiarid sage lands of southwestern Wyoming before its confluence with the Green River on the northwestern side of Flaming Gorge Reservoir (fig. 1). Blacks Fork, like many streams in the Colorado River Basin, adds salinity to the Colorado River (not shown) because some of the geologic formations over which the stream flows have highly dissolvable minerals that can mobilize when in contact with water and flow into the stream. The Bureau of Reclamation, in conjunction with the Colorado River Basin Salinity Control Forum, was interested in determining the contribution of dissolved solids from Blacks Fork above Smiths Fork (fig. 1) to the Colorado River (not shown) and initiated a study of Blacks Fork above Smiths Fork in 2018.

\section{Previous Studies}

Several studies describing discharge and water quality of Blacks Fork have been published by agencies and consultants to describe the hydrology of Blacks Fork. These studies have evaluated the system at different scales and with different foci including characterization, trend analyses, and base-flow input. Following is information about two reports that are particularly relevant to this study.

The Natural Resources Conservation Service (2006) described discharge measurements and water-quality sampling completed on Blacks Fork from Meeks Cabin Reservoir downstream to the formerly operational streamgage, Blacks Fork near Lyman, Wyoming, streamgage (U.S. Geological Survey [USGS] identifier 09222000) and the tributary, Threemile Creek (fig. 1). All streamgages described in the report were identified by the USGS and all subsequent identifications will only note the identifying number. The streamgage is about 4 miles downstream from the confluence of Blacks Fork and Smiths Fork (fig. 1). Data collected by the Natural Resource Conservation Service and the Uinta County Conservation District were used to calculate an estimated mean daily specific conductance and an estimated daily mean discharge, which were used to estimate an annual dissolved-solids load in Threemile Creek at the mouth.

The Natural Resources Conservation Service (2006) report also described dissolved-solids loads for water year 1965-83 at the Blacks Fork near Lyman, Wyo., streamgage (09222000) and at the Smiths Fork near Lyman, Wyo., streamgage (09221650; fig. 1). A water year is the 12-month period from October 1 through September 30 and designated by the calendar year for which it ends (water year 1965 is the period beginning October 1, 1964, and ending 


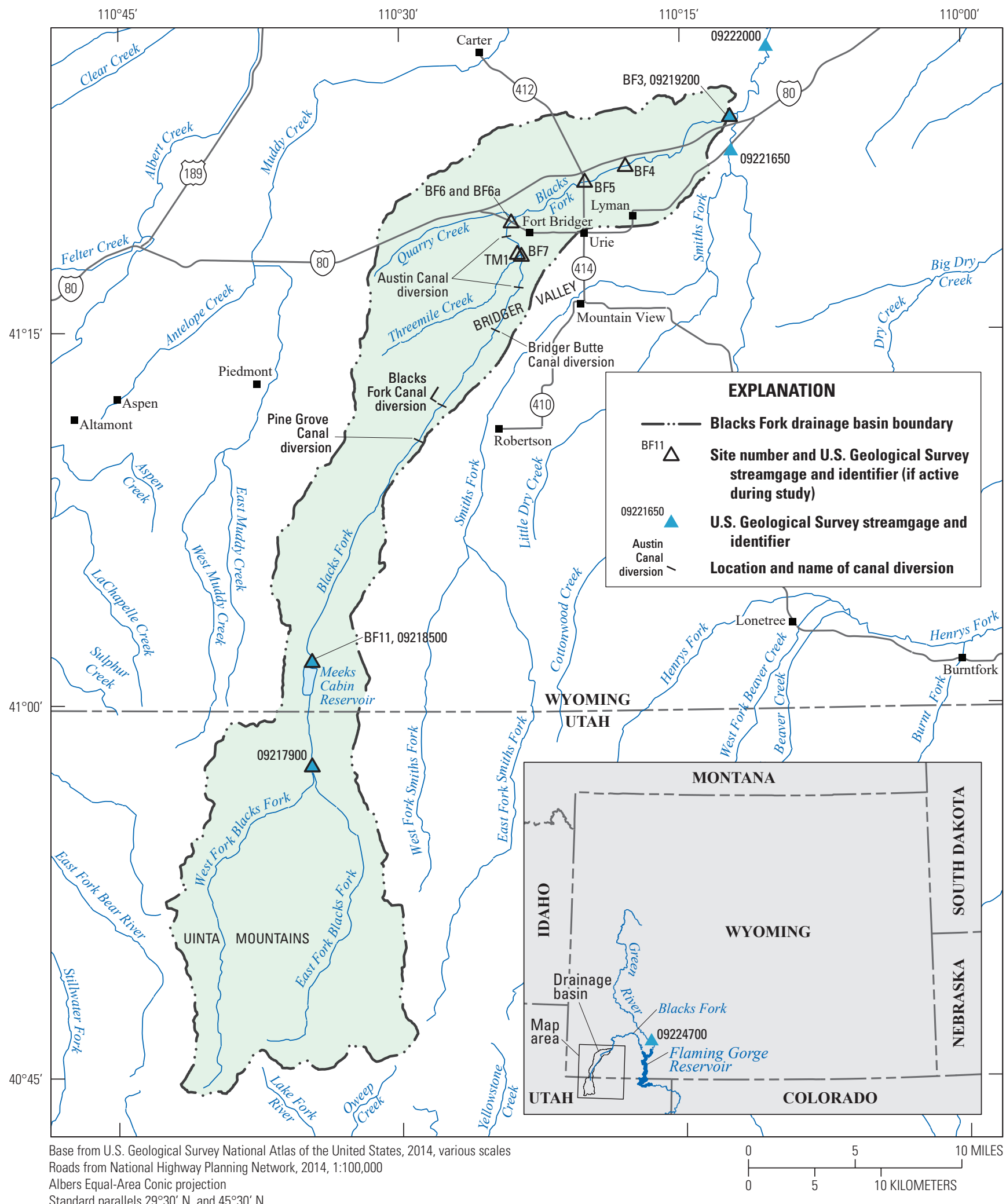

Standard parate $2930 \mathrm{~N}$ and $45{ }^{2}$

Central meridian $-96^{\circ} 00^{\prime} \mathrm{W}$.

North American Datum of 1983

Figure 1. Location and drainage basin of the Blacks Fork above Smiths Fork, near Lyman, Wyoming, streamgage (U.S. Geological Survey identifier 09219200) and continuous specific conductance monitor, synoptic sampling sites, and area streamgages. 
Discharge and Dissolved-Solids Characteristics of Blacks Fork above Smiths Fork, Wyoming

September 30, 1965). Loads at the Blacks Fork near Lyman, Wyo., streamgage (09222000) were calculated using daily discharge and daily specific conductance, along with instantaneously collected specific conductance and dissolved-solids sampling data. Calculated annual dissolved-solids loads at the Blacks Fork near Lyman, Wyo., streamgage (09222000) ranged from 32,700 to 226,000 tons per year (Natural Resources Conservation Service, 2006), and an estimate of the dissolved-solids load from the Smiths Fork near Lyman, Wyo., streamgage (09221650) also was determined. During 1974-89, instantaneous discharge and specific conductance were measured at the Smiths Fork near Lyman, Wyo., streamgage (09221650) at the same time discrete water-quality samples were collected to determine dissolved-solids concentrations. No continuous discharge data or specific conductance data were collected at the Smiths Fork near Lyman, Wyo., streamgage (09221650). A regression equation was used to estimate continuous discharge at the Smiths Fork near Lyman, Wyo., streamgage (09221650) using continuous discharge from the Blacks Fork near Lyman, Wyo., streamgage (09222000) and instantaneous discharge measurements made on or near the same day at the Smiths Fork near Lyman, Wyo., streamgage (09221650) and Blacks Fork near Lyman, Wyo., streamgage (09222000). The LOADEST model (Runkel and others, 2004) was then used to estimate the dissolved-solids load from the Smiths Fork using the estimated discharge data and the dissolved-solids concentrations from discrete water-quality samples collected at the Smiths Fork near Lyman, Wyo., streamgage (09221650). As noted in Natural Resources Conservation Service (2006), the estimate of dissolved-solids load at the Smiths Fork near Lyman, Wyo., streamgage (09221650) had an error greater than would be typically determined with the use of the LOADEST model (the estimated error was not presented) because the discharge measurements also were estimates. The magnitude of the error of the estimated dissolved-solids load is not known. Results of the dissolved-solids load analyses from the Blacks Fork near Lyman, Wyo., streamgage (09222000) and Smiths Fork near Lyman, Wyo., streamgage (09221650) indicated that an estimated 50 percent of the discharge and an estimated 25 percent of the dissolved-solids load at the Blacks Fork near Lyman, Wyo., streamgage (09222000) can be attributed to the Smiths Fork. As noted above, the error associated with these calculations is unknown.

A study from Sunrise Engineering (2013) completed in 2012 analyzed seepage of the canals in the Blacks Fork drainage basin and the Blacks Fork. Seepage rates for a canal in the drainage basin ranged from a gain of 0.39 to a loss of $4.26 \mathrm{ft}^{3} / \mathrm{s}$ on June 20, 2012 (Sunrise Engineering, 2013). The seepage investigations and associated sampling indicated that mean salt (dissolved-solids) concentrations from seeps are higher on the west (or north) side of Blacks Fork than from seeps on the east (or south) side of the river, and results indicated that the reason for the higher concentrations was due to the geology with which the groundwater interacted.

\section{Study Design}

Before this study, continuous discharge and salinity load data were not available for Blacks Fork above Smiths Fork, and estimates of the contribution of dissolved solids from Blacks Fork above Smiths Fork to the Colorado River system relied on data and estimates from other streamgages in the basin. The Bureau of Reclamation and Colorado River Basin Salinity Control Forum were interested in obtaining more accurate calculations of the current salinity contributions from Blacks Fork, just upstream from the confluence with the Smiths Fork, to isolate the contributions from the Blacks Fork before the reported diluting effects of the Smiths Fork. Additionally, collecting discharge and dissolved-solids samples along the main stem of the Blacks Fork and tributary sites in a synoptic, or snapshot, manner could be used to describe the locations and magnitude of water-quality changes in the Blacks Fork. These data also can be used to characterize the salinity loads in the Blacks Fork along the length of the stream during the middle to late growing season.

In early 2018 , to characterize the stream, a streamgage was installed at the most downstream location on the Blacks Fork upstream from the convergence with Smiths Fork. The Blacks Fork above Smiths Fork, near Lyman, Wyo., streamgage (09219200) (fig. 1) streamgage was operated from April 4, 2018, through September 30, 2019, with instrumentation collecting continuous stream stage and specificconductance data. Water samples were collected and analyzed for dissolved-solids concentrations in addition to measurements of discharge and specific conductance.

Seven sites were used for a synoptic study to describe the discharge and dissolved-solids concentrations and loads. All synoptic sampling locations are referred to as "sites," regardless of whether they are currently operated streamgages, formerly operated streamgages, or sites established for the purpose of this study. Sites were selected based on accessibility, influence of tributaries, quality of discharge measurement and water-quality sample collection cross sections, and sites used by Uinta County Conservation District, Natural Resource Conservation Service, and others (Natural Resources Conservation Service, 2006). Two of the selected sites were currently operated streamgages, Blacks Fork near Millburne, Wyo., (09218500) and Blacks Fork above Smiths Fork, near Lyman, Wyo., (09219200). The streamgages were the most upstream (streamgage 09218500) and downstream (streamgage 09219200) sites sampled during the synoptic sampling. Five additional sites (table 1) were selected to provide a synoptic description of Blacks Fork in a downstream manner and were sampled during the summers of 2018 and 2019 (BF7, TM1, BF6/BF6a, BF5, and BF4). At the time of site selection, one site (BF6) was established at a location below (downstream from) an inflowing drain. However, the decision was made that a new site (BF6a) above (upstream from) the drain would be sampled during subsequent synoptic sampling events to minimize variability that could occur at the site due to the addition of the water from the drain. During the 
Table 1. Discharge and dissolved-solids synoptic sampling sites (including streamgages) used to study Blacks Fork above Smiths Fork, April 2018 through September 2019.

[USGS, U.S. Geological Survey; Wyo., Wyoming]

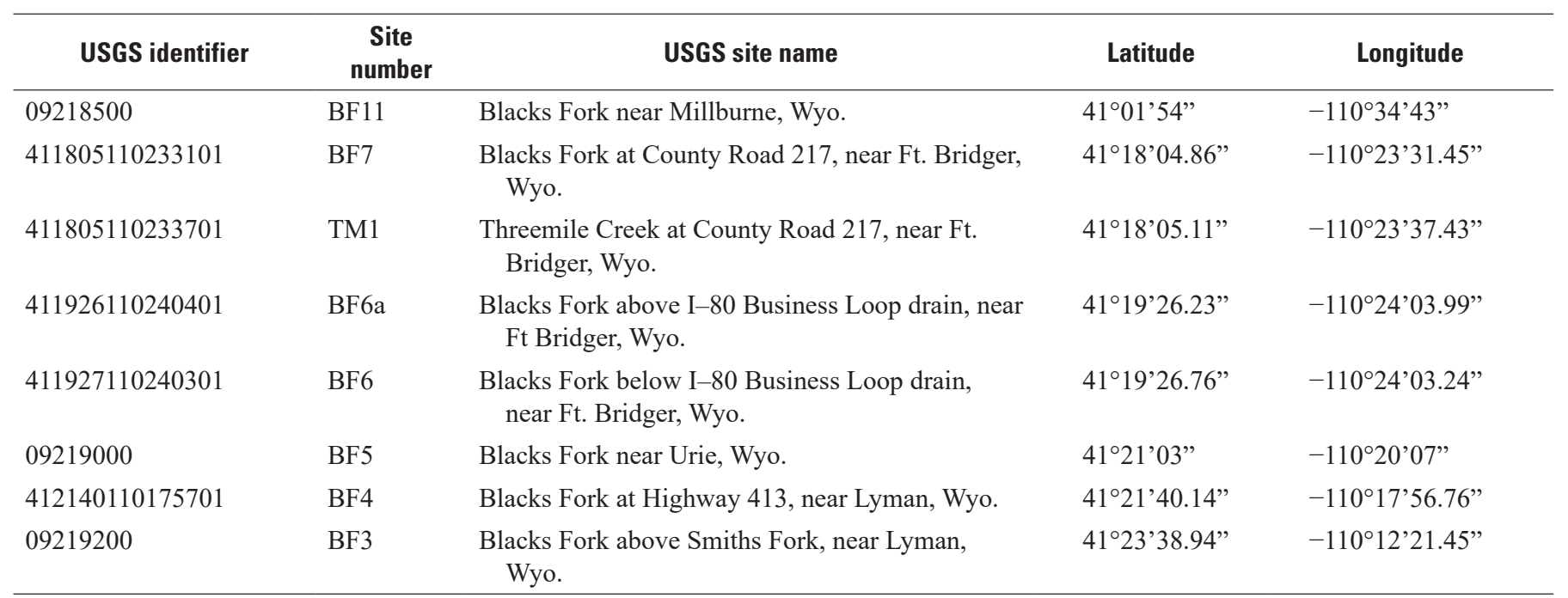

first sampling, minimal flow was entering the main stem from the drain, so the data from BF6 are assumed to be similar to BF6a during the July 2018 sample, and data for BF6 and BF6a are used to describe the single location (BF6a).

\section{Purpose and Scope}

The purpose of this report is to (1) characterize continuous discharge and specific conductance at the most downstream location of the Blacks Fork above the Smiths Fork confluence; (2) determine the daily mean discharge, daily mean dissolved-solids concentration, and daily mean dissolved-solids load for the period from April 2018 through September 2019; and (3) determine the instantaneous salinity load in the Blacks Fork drainage area upstream from the Blacks Fork above Smiths Fork confluence at selected sites using synoptic water-quality samples from the Blacks Fork and an input (tributary Threemile Creek) during 2018 and 2019 irrigation seasons to describe changes in discharge, dissolved-solids concentrations, and dissolved-solids loads during seven sampling periods. 
Discharge and Dissolved-Solids Characteristics of Blacks Fork above Smiths Fork, Wyoming

\section{Study Area}

The study area for the project is the Blacks Fork upstream from the confluence of the Smiths Fork, primarily in Wyoming. Blacks Fork originates in the Uinta Mountains in Utah at elevations higher than 13,000 feet (U.S. Geological Survey, 1982) and flows northerly through a narrow band of montane/subalpine forests (U.S. Geological Survey, 1982) into the Meeks Cabin Reservoir (fig. 1). Downstream from Meeks Cabin Reservoir, the narrow basin transitions into the Bridger Valley, foothill shrublands and woodlands, and then to sagebrush steppe (Carr and Melcher, 2017). The lower basin, mostly in the sagebrush steep, is the primary area where irrigated agriculture occurs (Carr and Melcher, 2017). Data collection efforts were focused on the about 25-mile reach of the Blacks Fork from just upstream from Threemile Creek to just upstream from the confluence with Smiths Fork.

\section{General Hydrology}

The drainage area contributing flow into Blacks Fork above Smiths Fork, near Lyman, Wyo. (09219200) (fig. 1) is about 325 square miles (U.S. Geological Survey, 2020b). Below Meeks Cabin Reservoir, the stream flows northward and during irrigation season, about 20 to 60 percent of the discharge from the reservoir is diverted into the Blacks Fork Canal (fig. 1) (Wyoming State Engineer's Office, 2021), at which point the diverted water becomes part of the Smiths Fork drainage. Streamflow below the Blacks Fork Canal is diverted into three major canals that flow to the west side of Blacks Fork - the Pine Grove, Bridger Butte, and Austin Canals (fig. 1) - and most of the diverted water remains in the drainage basin above the Blacks Fork above Smiths Fork, near Lyman, Wyo., streamgage (09219200) (Natural Resources Conservation Service, 2006; Sunrise Engineering, 2013). Some water returns to the river upstream from the streamgage through return flows or groundwater but other diverted water continues to flow northward and returns enter Blacks Fork downstream from the Smiths Fork confluence (Natural Resources Conservation Service, 2006; Sunrise Engineering, 2013).

The source of discharge at the Blacks Fork above Smiths Fork, near Lyman, Wyo., streamgage (09219200) is a combination of release from Meeks Cabin Reservoir, snowmelt runoff, precipitation, irrigation return flows, and groundwater discharge. The proportion of those sources varies by year and season. The construction of Meeks Cabin Reservoir in the late 1960s allowed spring snowmelt runoff to be retained which extended the irrigation season in the Bridger Valley. Meeks Cabin Reservoir operations result in decreased spring peak flows and increased summer flows at the reservoir outflow (Bureau of Reclamation, 2021). Releases from the reservoir during the summer seasons are diverted upstream from the Blacks Fork near Lyman, Wyo., streamgage (09222000) for agricultural use (irrigation and some stock watering), and the discharge at the Blacks Fork above Smiths Fork, near Lyman, Wyo., streamgage (09219200) is affected by both of these operations.

\section{Climate}

The climate of the basin downstream from Meeks Cabin is characterized by cold winters and warm to hot summers. The highest amounts of precipitation fall in the higher elevations in the southern part of the basin. Temperature and precipitation data have been collected at a weather station in Mountain View, Wyo. (fig. 1) since 1966 (Western Regional Climate Center, 2020; period of record 1966-2015). Although Mountain View is a few miles east of the Blacks Fork above Smiths Fork drainage basin, the location is appropriate to describe general climate in the mid to lower Bridger Valley. Data from the Mountain View weather station indicates a mean temperature of 41.9 degrees Fahrenheit $\left({ }^{\circ} \mathrm{F}\right)$ with the coldest temperatures measured during January (mean monthly temperature $22.3^{\circ} \mathrm{F}$ ) and the warmest temperatures measured during July (mean monthly temperature, $64.3^{\circ} \mathrm{F}$ ). More precipitation falls during spring (April, May, and June) and late summer/fall (September and October) than other times of the year, with a mean annual precipitation of 9.6 inches (Western Regional Climate Center, 2020; period of record, 1966-2015).

Data from the Mountain View weather station (NOAA Regional Climate Centers, 2020) indicates that the weather was warmer and drier than normal during water year 2018 (October 1, 2017, through September 30, 2018) and cooler and wetter than normal during water year 2019 (October 1, 2018, through September 30, 2019). During water year 2018, the station had a mean annual temperature of $46.4^{\circ} \mathrm{F}$; the mean temperature during April and September 2018 was $57.9^{\circ} \mathrm{F}$. Temperatures during water year 2019 were lower than the mean, with a mean annual temperature of $40.4^{\circ} \mathrm{F}$. The mean temperature during April through September 2019 was $54.2^{\circ} \mathrm{F}$. The Mountain View weather station indicates precipitation during water year 2018 was less than the mean, with a cumulative 7.4 inches (4.2 inches between April and September 2018). Precipitation during water year 2019 at Mountain View was greater than the mean and almost twice as much as 2018 , with a cumulative 14.3 inches ( 8.5 inches between April and September 2019).

\section{Geology}

The Blacks Fork drainage basin resides within the physiographic Bridger Basin (Koenig, 1960; not shown), which is part of the greater Green River structural basin of southwestern Wyoming. Tributaries of the Blacks Fork drainage flow northeast into the Green River structural basin. The southern boundary of the Bridger Basin is bounded by the Uinta Mountains of Utah, and the eastern boundary is restricted by the Central Rocky Mountains (not shown) (Robinove and Cummings, 1963; Murphey and Evanoff, 2007). 
Because of study objectives, only surficial deposits and bedrock units that crop out within the Blacks Fork drainage basin are discussed. Surficial deposits and bedrock units within and near the drainage basin are shown in figure 2 (modified from Love and Christiansen, 1985).

Several types of surficial deposits are in the drainage basin (fig. 2). Quaternary-age alluvial (Qa) and terrace (Qt) deposits constitute most of the surficial sediments within the Blacks Fork drainage basin (Robinove and Cummings, 1963; fig. 2). During valley development, strath terraces (surfaces cut into bedrock by eroding streams) running parallel to the drainage were developed by Blacks Fork, Smiths Fork, and tributaries through lateral planation during interglacial stages. During glacial-stage and immediate postglacial stage, flooding created more drastic downcutting of the erosional surfaces and deposited currently exposed alluvial and terrace deposits (Bradley, 1936). The strath terraces truncate the Bridger Formation between the Blacks Fork and Smiths Fork drainages exposing sediments. The alluvial (Qa) and terrace deposits (Qt) consist of poorly sorted silt, sand, and gravel with clasts consisting largely of quartzite; lithologies of the two deposits are similar, making them difficult to distinguish from one another (Robinove and Cummings, 1963).

Additionally, Quaternary-age glacial deposits (Qg) consisting of poorly sorted silt, sand, gravel, and boulders within the Blacks Fork drainage basin were deposited during the Blacks Fork and Smiths Fork glacial stages. Blacks Fork stage deposits are distinguished from the Smiths Fork stage deposits by a more boulder-inclusive matrix, as well as increased soil content (Robinove and Cummings, 1963). Glacial deposits consisting of frontal and terminal moraines throughout the valley of the drainage basin are attributed to the Blacks Fork glacial stage. The Smiths Fork stage left terminal moraines within the canyons of the drainage basin upstream from the previous stage, indicating a less extensive extent than the Blacks Fork stage glacial deposits within the drainage basin (Bradley, 1936).

Bedrock units that crop out within the Blacks Forks drainage basin consist of the Bridger Formation (Tb, fig. 2) and the Bishop Conglomerate (Tbi, fig. 2). The Tertiary-age Bridger Formation consists of green to gray calcareous shales and siltstones with tuffaceous sandstones as well as limestone beds. Sediments consisting of the Bridger Formation were accumulated through fluvial, deltaic, and lacustrine deposition as the lower relief topography of the stream valleys and lakes of the greater Green River structural basin were filled (Robinove and Cummings, 1963). Volcanic material was intermixed within all sediment layers of the Bridger Formation as ash deposited on valley flats during periods of greater volcanic activity was reworked and redeposited within the waterbodies and floodplains (Koenig, 1960). The Tertiary-age Bishop Conglomerate consists of pebbles and cobbles of limestone as well as black and red chert primarily sourced from the Uinta Mountain Group. Gray and white medium to course grained sands are the primary matrix associated with the conglomerate (Bradley, 1936). 


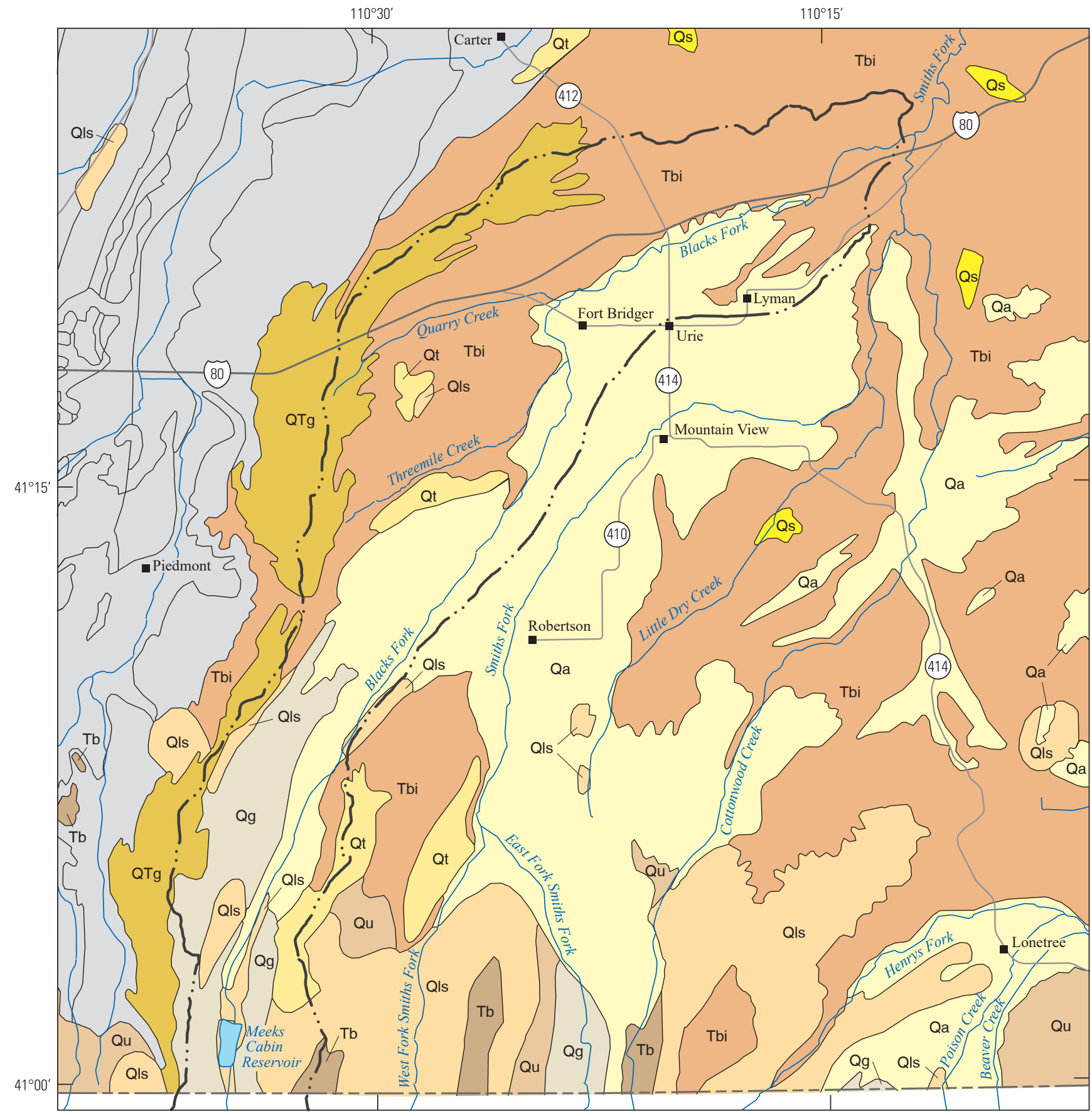

Base from U.S. Geological Survey National Atlas of the United States, 2014, various scales Roads from National Highway Planning Network, 2014, 1:100,000 Albers Equal-Area Conic projection

Standard parallels $29^{\circ} 30^{\prime} \mathrm{N}$. and $45^{\circ} 30^{\prime} \mathrm{N}$.

Central meridian $-96^{\circ} 00^{\prime} \mathrm{W}$.

North American Datum of 1983

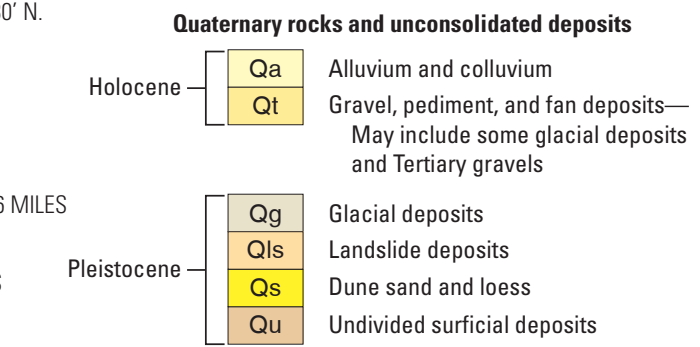

EXPLANATION

Geology from Love and Christiansen, 1985

List of map units in the Blacks Fork Basin 


\section{Methods}

Methods for collection of continuous and discrete discharge and specific conductance, for collection of discrete water-quality samples for dissolved solids, and the laboratory method for analyzing dissolved-solids determination are discussed in this section. Data-analysis methods for statistically describing the relation between specific conductance and dissolved solids also are discussed in this section.

\section{Discharge Measurements}

All discharge measurement methods followed standard USGS discharge measurement protocols (Rantz and others, 1982a; Nolan and Shields, 2000; Turnipseed and Sauer, 2010). Acoustic Doppler velocity meters and acoustic Doppler current profiler meters were used exclusively because of their ability to provide high-resolution velocity data and their suitability in shallow stream environments. Under optimal conditions, measurement error using these methods is typically less than plus or minus 5 percent. Depending on the time of year and the channel geometry at some of the specific streamgages and sites, factors such as ice or an abundance of aquatic plants in the cross section made conditions less than optimal. Therefore, discharge measurements were qualitatively classified as "Good," "Fair," or "Poor" according to standard USGS protocol (Turnipseed and Sauer, 2010), and measurement accuracy for all measurements was between 95 and about 90 percent (U.S. Geological Survey, 2020a, U.S. Geological Survey, 2021a).

The development of a rating curve for the Blacks Fork above Smiths Fork, near Lyman, Wyo., streamgage (09219200) was completed after all data were collected to a create continuous discharge record from the collected continuous stream-stage data using techniques described in Rantz and others (1982b). As noted in the water year summaries for 2018 and 2019, the daily mean values for discharge are "Fair" (indicating accuracy of about 92 percent) during the year, except during times when the stage is affected by ice and, then, the discharge is estimated (U.S. Geological Survey, 2020b). Estimated data are assumed to be "Poor," indicating that accuracy of the data is less than 90 percent (Turnipseed and Sauer, 2010).

\section{Specific Conductance and Dissolved Solids}

Specific conductance is the measure of the electrical conductivity of water. This property can be measured continuously with a probe and is often used as a surrogate for determining the dissolved-solids concentrations (Clark and
Davidson, 2009, Shope and Gerner, 2014). Specific conductance was measured in the field using a calibrated probe for continuous and instantaneous values.

Field methods used for the water-quality sampling followed standard methods described in the "National Field Manual for the Collection of Water-Quality Data" (U.S. Geological Survey, variously dated). Water-quality samples were collected using a DH-81 sampler, and depth-integrated samples were collected using equal-width increments.

Samples were filtered and sent to the USGS National Water Quality Laboratory in Lakewood, Colorado, for analyses of dissolved solids using the residue on evaporation method (Fishman and Friedman, 1989).

To ensure the quality of the data collection and analytical methods, five quality assurance samples (one blank and four replicates) were collected. The blank sample was collected using purchased inorganic blank water and was "sampled" and processed in the same manner as an environmental sample that was collected after cleaning the equipment. Analytical results from the laboratory indicated no dissolved solids were detected (less than 20 milligrams per liter [mg/L]) in the blank sample, indicating that the equipment cleaning after sampling at each site was adequate to prevent cross contamination.

The replicate samples were collected and processed in the same manner as the environmental sample and were used to determine the repeatability of the sampling methods and laboratory analyses of dissolved-solids concentrations. The dissolved-solids concentration data and results of the relative percent difference calculations between the environmental sample and the replicated sample are presented in appendix 1 . The sample sets had relative percent differences in dissolved-solids concentrations ranging from 0.88 to 3.80 , which indicates the dissolved-solids data can be used without adjustments.

\section{Data Analysis}

Measured continuous specific-conductance data were used to estimate a continuous dissolved-solids record using methods documented in other studies such as Clark and Davidson (2009). Linear regression is a technique for estimating one water-quality variable based on another water-quality variable (Helsel and others, 2020). A linear, least-squares regression model of dissolved solids and specific conductance was developed using 22 samples collected during the 18 months of the study to estimate continuous dissolved-solids concentrations. Daily mean dissolved-solids concentrations were then calculated for the Blacks Fork above Smiths Fork, near Lyman, Wyo., streamgage (09219200). 
Daily mean discharge and daily mean dissolvedsolids concentrations were used to calculate the continuous dissolved-solids load. Because actual values of discharge and dissolved-solids concentrations were collected and calculated on a daily basis, models such as LOADEST or WRTDS (Hirsch and others, 2010) were not needed to estimate the loads. Daily mean dissolved-solids loads were calculated as the product of the discharge and dissolved-solids concentration by the following equation:

$$
D S L=Q^{*} D S^{*} b
$$

where

$D S L \quad \begin{gathered}\text { is the daily mean dissolved-solids load, in } \\ \text { tons per day; }\end{gathered}$
$Q \quad$ is the daily mean discharge in, cubic feet
per second;
$D S \quad$ is the daily mean dissolved-solids
concentration, in milligrams per liter; and
$b \quad$ is $2.69 \times 10^{-3}$, a unit conversion factor.

\section{Discharge, Specific Conductance, and Dissolved-Solids Characteristics at the Blacks Fork above Smiths Fork, near Lyman, Wyoming, Streamgage}

Continuous discharge and specific-conductance data were collected from April 4, 2018, through September 30, 2019, at the Blacks Fork above Smiths Fork, near Lyman, Wyo., streamgage (09219200) (U.S. Geological Survey, 2020a). During the 18-month study, daily mean discharge ranged from a minimum $0.01 \mathrm{ft}^{3} / \mathrm{s}$ to a maximum of $651 \mathrm{ft}^{3} / \mathrm{s}$ (fig. 3, U.S. Geological Survey, 2020b), with a mean daily (mean of the daily mean) discharge of $59.1 \mathrm{ft}^{3} / \mathrm{s}$ (U.S. Geological Survey, 2020b). The daily mean specific conductance during the same period ranged from 677 microsiemens per centimeter at 25 degrees Celsius $(\mu \mathrm{S} / \mathrm{cm})$ to a maximum of 3,360 $\mu \mathrm{S} /$ cm (fig. 3, U.S. Geological Survey, 2020b). Twenty-two discrete samples were collected on a near monthly basis, and dissolved-solids concentrations in those samples ranged from 629 to $2,970 \mathrm{mg} / \mathrm{L}$ (U.S. Geological Survey, 2020b).

\section{Discharge}

Discharge at the Blacks Fork above Smiths Fork, near Lyman, Wyo., streamgage (09219200) is affected primarily by precipitation in the basin, releases from the Meeks Cabin Reservoir, diversions, and return flows (direct and through groundwater). Discharge at the streamgage is typically higher in the spring and early summer because of snowmelt, increases for a short period in response to local precipitation, and maintains a steady base flow during the late fall and winter from upstream flow and groundwater (base-flow) inputs (fig. 3). Discharge during April through September 2018 was lower and less variable than during the same period in 2019 (fig. 4). The mean daily discharge during those 6 months in $2018(15.1 \mathrm{ft} 3 / \mathrm{s})$ was about one-tenth of the discharge during the same period in $2019\left(152 \mathrm{ft}^{3} / \mathrm{s}\right)$ (U.S. Geological Survey, 2021b). The cumulative discharge from April through September in 2018 (5,362 acre-feet) was about 10 percent of the discharge recorded during the same period in 2019 $(54,660$ acre-feet) (table 2). These various metrics reflect the different climatic water years, with water year 2018 being a warmer and drier year than normal and water year 2019 being a cooler and wetter than normal.

Discharge during the spring and summer (April through September) of 2018 at three long-term streamgages on Blacks Fork (Blacks Fork near Robertson, Wyo. [09217900]; Blacks Fork near Millburne, Wyo. [09218500]; and Blacks Fork near Little America, Wyo. [09224700]) (fig. 1) was lower or substantially lower compared to the mean during the last 30 years, whereas discharge during the spring and summer of 2019 was higher than mean (table 2). The timing of the highest flows for all four Blacks Fork streamgages also was different during 2018 and 2019 (fig. 5), with the highest flows generally occurring during May in 2018 and during June in 2019. The Blacks Fork above Smiths Fork, near Lyman, Wyo., streamgage (09219200) and Blacks Fork near Little America, Wyo., streamgage (09224700) have drainage basins that include the sagebrush steppe and the higher-elevation mountains. These two streamagages show two periods of high flow, in 2019, during April and June (fig. 5), indicating that the melting of low elevation snowpack likely provided a noticeable contribution to discharge during 2019.

\section{Specific Conductance}

Specific conductance measured at the Blacks Fork above Smiths Fork, near Lyman, Wyo., streamgage (09219200) during the 18-month study had daily mean values ranging from $677 \mu \mathrm{S} / \mathrm{cm}$ to 3,360 $\mu \mathrm{S} / \mathrm{cm}$ (fig. 3, U.S. Geological Survey, 2020b; U.S. Geological Survey, 2021b). Specific conductance values were less variable in the winter when precipitation fell as snow, limiting the amount of runoff reaching the stream.

\section{Dissolved-Solids Concentrations}

Estimated daily mean dissolved-solids concentrations were calculated using the daily mean specific conductance values and the relation between specific conductance and dissolved-solids concentration at the Blacks Fork above Smiths Fork, near Lyman, Wyo., streamgage (09219200). The specific conductance and dissolved-solids relation was calculated using 22 discrete samples collected during the 18-month study; figure 6 shows the specific conductance and dissolvedsolids concentration for each sample collected. The specific 

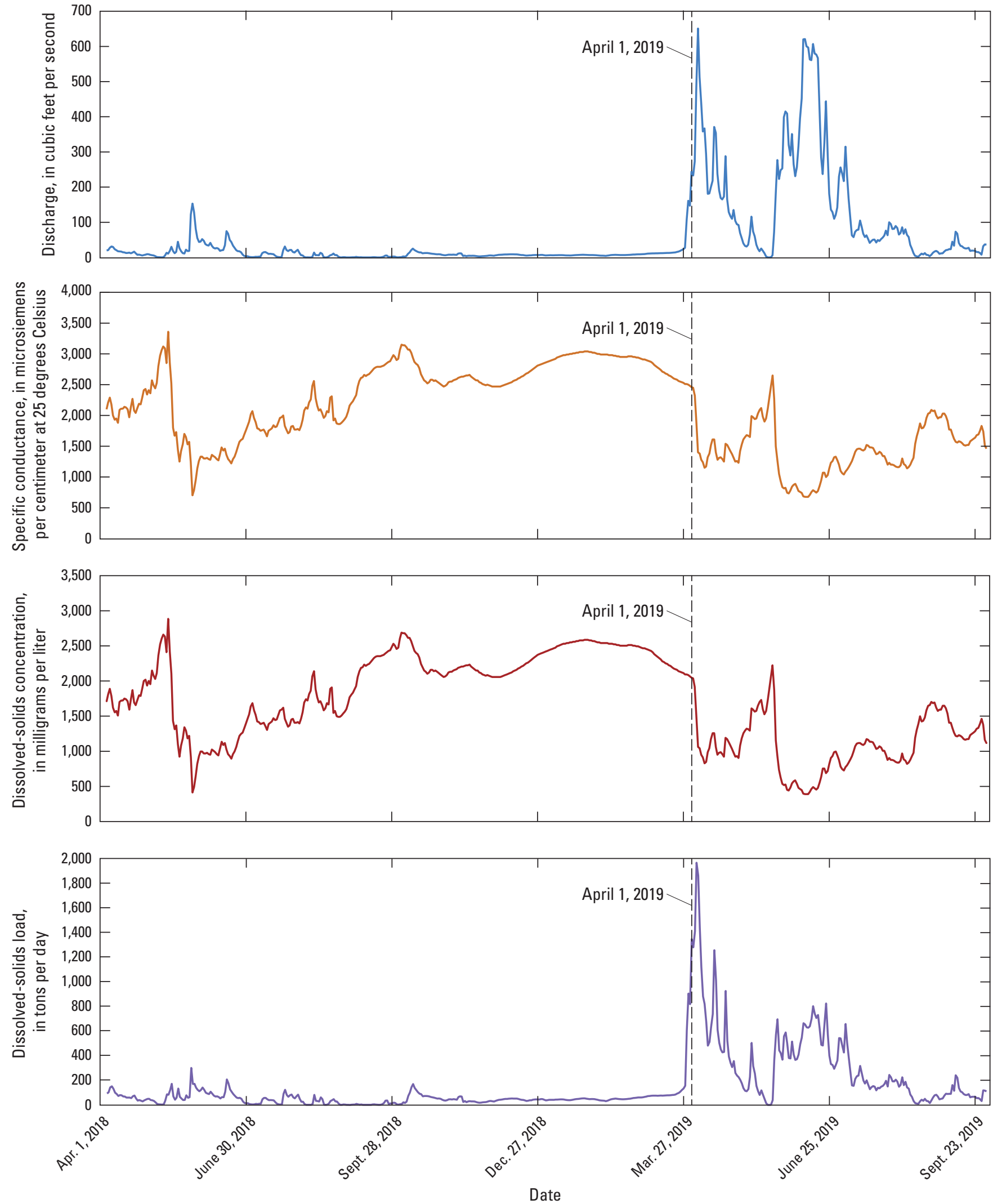

Figure 3. Daily mean discharge, daily mean specific conductance, daily mean dissolved-solids concentration, and daily mean dissolved-solids load at the Blacks Fork above Smiths Fork, near Lyman, Wyoming, streamgage (09219200), April 5, 2018, through September 30, 2019. 
Table 2. Drainage basin area and cumulative discharge for Blacks Fork streamgages during the 6-month period from April through September 2018 and April through September 2019.

[USGS, U.S. Geological Survey; mi², square mile; Wyo., Wyoming; NA, not applicable]

\begin{tabular}{|c|c|c|c|c|}
\hline \multirow{2}{*}{ USGS streamgage name and identifier } & \multirow{2}{*}{$\begin{array}{l}\text { Drainage } \\
\text { area } \\
\left(\mathrm{mi}^{2}\right)\end{array}$} & \multicolumn{3}{|c|}{$\begin{array}{l}\text { Cumulative discharge from } \\
\text { April through September } \\
\text { (acre-feet) }\end{array}$} \\
\hline & & 2018 & 2019 & $\begin{array}{c}\text { Mean } \\
\text { during } \\
\text { 1990-2019 }\end{array}$ \\
\hline Blacks Fork near Robertson, Wyo. (09217900) & 130 & 87,480 & 144,720 & 193,180 \\
\hline Blacks Fork above Smiths Fork near, Lyman, Wyo. (09219200) & 324 & 5,362 & 54,660 & NA \\
\hline Blacks Fork near Little America, Wyo. (09224700) & 3,100 & 58,710 & 209,830 & 129,280 \\
\hline
\end{tabular}

'Discharge data collected during this period were from 1990 through 1998 and from 2013 through 2019.

${ }^{2}$ Discharge data collected during this period were from 1993 through 2019.

conductance values of the discrete samples ranged from 888 to $3,340 \mu \mathrm{S} / \mathrm{cm}$ and had a range similar to specific conductance values recorded at the streamgage during the study period (fig. 3). A linear, least-squares regression model of dissolved solids and specific conductance was developed and produced the following equation:

$$
D S=0.928(S C)-239
$$

where

$$
\begin{aligned}
& D S \quad \text { is the dissolved-solids concentration, in } \\
& \text { milligrams per liter; and } \\
& \text { is the specific conductance, in microsiemens } \\
& \text { per centimeter at } 25 \text { degrees Celsius, } \\
& \text { (coefficient of determination }=0.994, \\
& \left.p \text {-value }<7 \times 10^{-24}\right) .
\end{aligned}
$$

Daily mean dissolved-solids concentrations are listed in table 3 and shown in figure 3. Dissolved solids often have an inverse relation to discharge because higher discharges typically have a diluting effect that lowers the dissolvedsolids concentrations. Figure 7 shows that, in general, when discharges at the Blacks Fork above Smiths Fork, near Lyman, Wyo., streamgage (09219200) are higher, dissolved-solids concentrations are lower. However, the high dissolved-solids concentrations that are measured during high discharges indicate that the system has natural variability and the dissolvedsolids concentrations are determined by more factors than just discharge. Figure 7 illustrates that estimating dissolved-solids concentrations using a model based primarily on discharge has the potential to generate considerable variability in the estimates.
Data from the study period indicate that, although the high flows in May 2018 were lower in magnitude than high flows in April or June 2019, the dilution of the dissolved solids in the stream from additional flow in 2019 was not substantial (fig. 3). The dissolved-solids concentration decreased to a similar concentration in both years during the late spring and early summer. The dissolved-solids concentrations during the summer of 2019 were somewhat lower than in 2018 and is likely because of dilution from rainfall events. The range of values shown in figure 4 and listed in table 3 indicate that the April through September daily mean dissolved-solids concentrations were typically higher in 2018 than 2019, and the mean daily dissolved-solids concentration was higher in 2018 $(1,630 \mathrm{mg} / \mathrm{L})$ than in $2019(1,100 \mathrm{mg} / \mathrm{L})$.

Snowmelt and rainfall originating from different areas or elevations within the drainage basin and their contribution to runoff and streamflow likely affect the dissolved-solids concentrations observed in the stream. The observed temporal pattern of dissolved-solids concentration is likely a response to early, low dissolved-solids snowmelt from the lower-elevation sagebrush steppe landscape during the spring and, then, from snowmelt in higher elevations during early summer. As snowmelt discharge subsided in the summer, the reduced discharge upstream and direct return flows from irrigation or return flows through groundwater discharge likely led to the general increase in dissolved-solids concentration. Dissolved-solids concentrations were higher in the winter and early spring, in part, because of the decreased discharge upstream during this period, and predominance of base flow from groundwater that has likely flowed through geology with higher dissolvable solids as a primary source of discharge. 

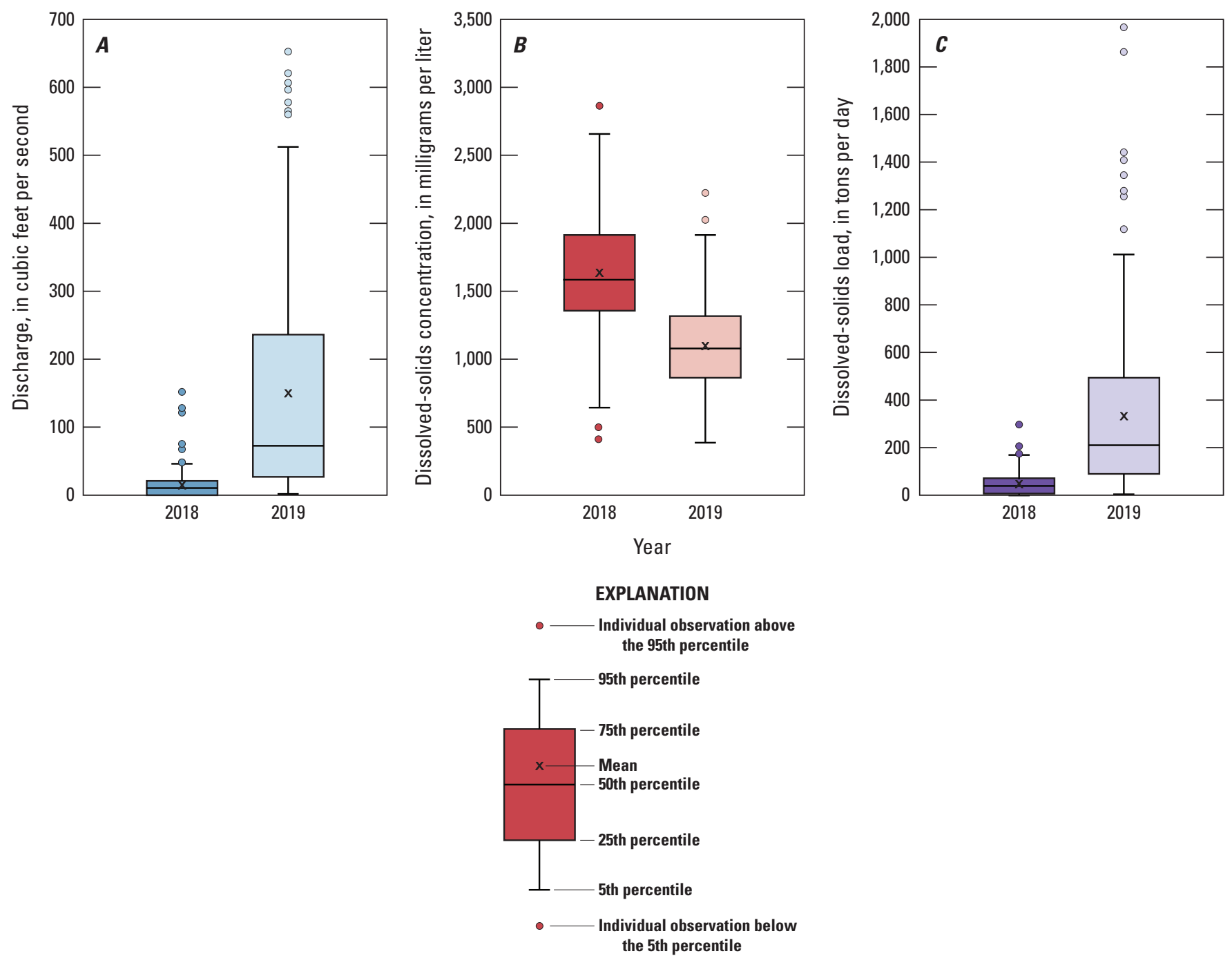

Figure 4. Box plots showing distribution of daily mean values for the Blacks Fork above Smiths Fork, near Lyman, Wyoming, streamgage (09219200), April through September 2018 and April through September 2019. $A$, discharge; $B$, dissolved-solids concentration; and $C$, dissolved-solids load. 


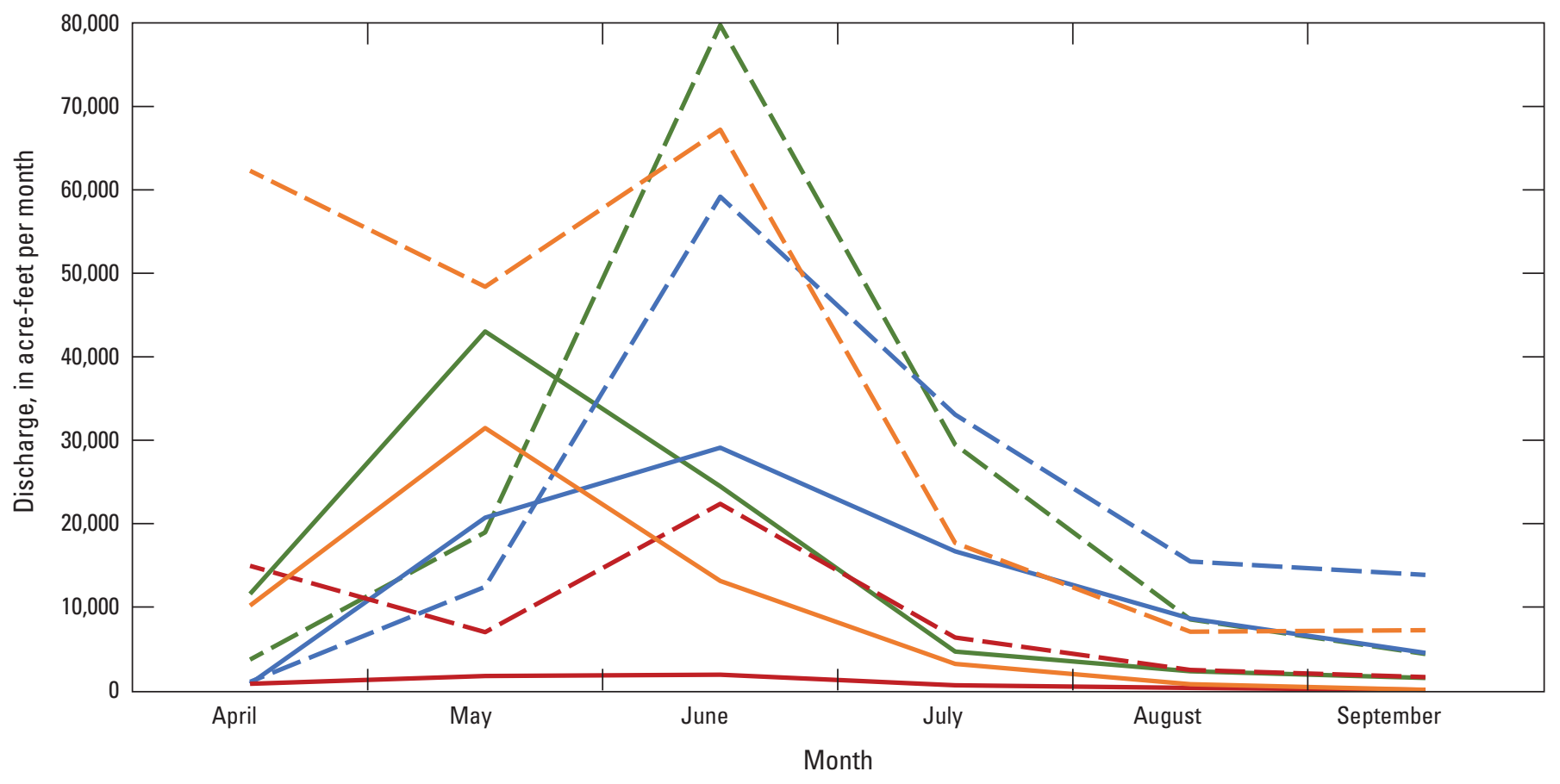

\section{EXPLANATION}

Blacks Fork near Robertson, Wyo.

(U.S. Geological Survey [USGS] streamgage 09217900)

2018 monthly mean streamflow

- — - 2019 monthly mean streamflow

Blacks Fork near Millburne, Wyo., site BF11 (USGS streamgage 09218500)

___ - 2018 monthly mean streamflow

Blacks Fork above Smiths Fork near Lyman, Wyo., site BF3 (USGS streamgage 09219200)

2018 monthly mean streamflow

- _ - 2019 monthly mean streamflow

Blacks Fork near Little America, Wyo. (USGS streamgage 09224700)

2018 monthly mean streamflow

_ _ _ 2019 monthly mean streamflow

Figure 5. Monthly discharge at four Blacks Fork streamgages during April through September 2018 and April through September 2019 : Blacks Fork near Robertson, Wyoming (09217900), Blacks Fork near Millburne, Wyoming (09218500), Blacks Fork above Smiths Fork, near Lyman, Wyoming (09219200), and Blacks Fork near Little America, Wyoming (09224700). 


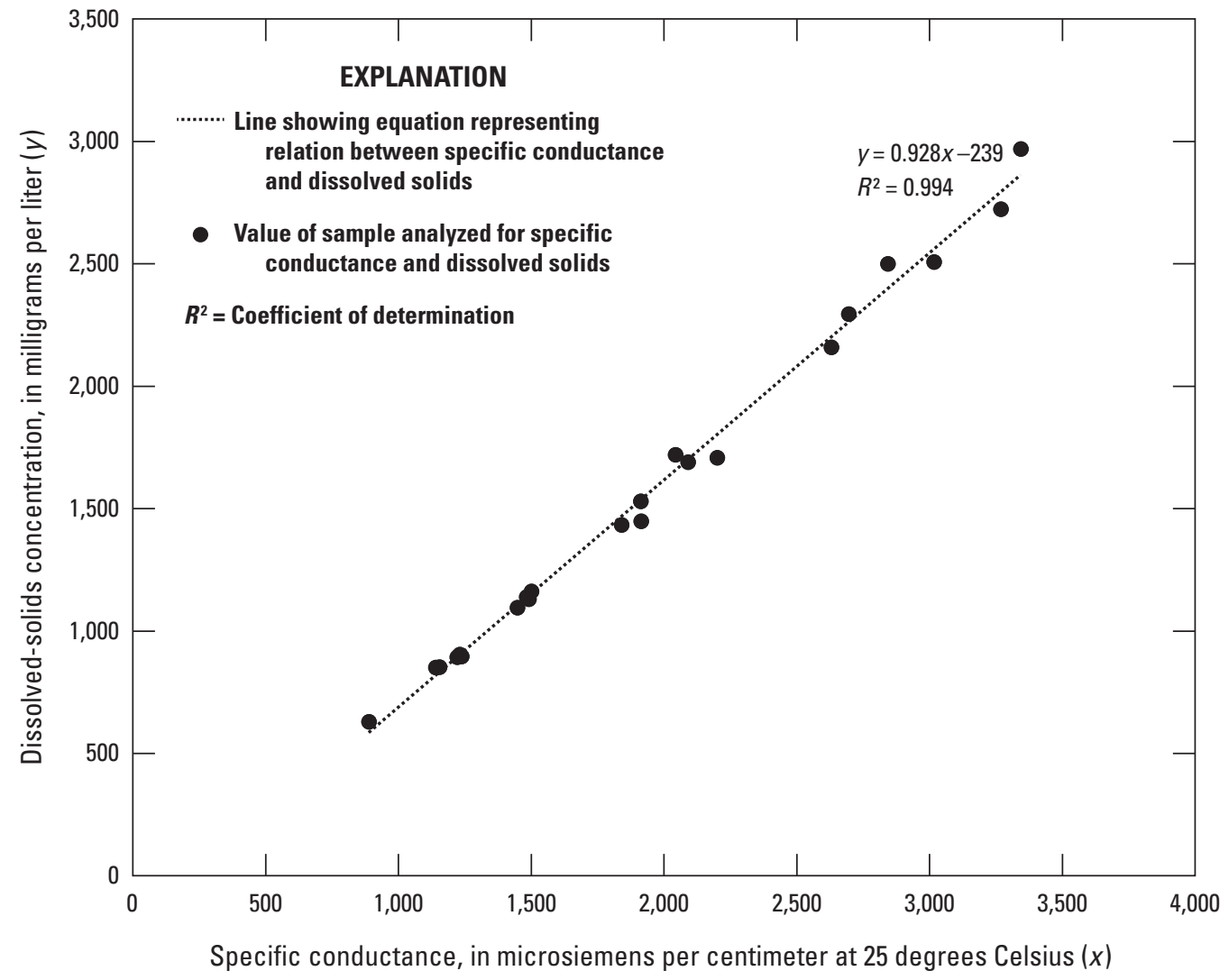

Figure 6. Linear regression between specific conductance and dissolved solids calculated using samples collected during April 4, 2018, through October 2, 2019, at the Blacks Fork above Smiths Fork, near Lyman, Wyoming, streamgage (09219200). 
Table 3. Daily mean dissolved-solids concentration; mean, minimum, and maximum of daily mean dissolved-solids concentration for each month during April 5, 2018, through September 30, 2019, Blacks Fork above Smiths Fork, near Lyman, Wyoming, streamgage (09219200).

[--, no data]

\begin{tabular}{|c|c|c|c|c|c|c|c|c|c|c|c|c|c|c|c|c|c|c|}
\hline Day & $\begin{array}{l}\text { Apr. } \\
2018\end{array}$ & $\begin{array}{l}\text { May } \\
2018\end{array}$ & $\begin{array}{l}\text { June } \\
2018\end{array}$ & $\begin{array}{l}\text { July } \\
2018\end{array}$ & $\begin{array}{l}\text { Aug. } \\
2018\end{array}$ & $\begin{array}{l}\text { Sept. } \\
2018\end{array}$ & $\begin{array}{l}\text { Oct. } \\
2018\end{array}$ & $\begin{array}{l}\text { Nov. } \\
2018\end{array}$ & $\begin{array}{l}\text { Dec. } \\
2018\end{array}$ & $\begin{array}{l}\text { Jan. } \\
2019\end{array}$ & $\begin{array}{l}\text { Feb. } \\
2019\end{array}$ & $\begin{array}{l}\text { Mar. } \\
2019\end{array}$ & $\begin{array}{l}\text { Apr. } \\
2019\end{array}$ & $\begin{array}{l}\text { May } \\
2019\end{array}$ & $\begin{array}{l}\text { June } \\
2019\end{array}$ & $\begin{array}{l}\text { July } \\
2019\end{array}$ & $\begin{array}{l}\text { Aug. } \\
2019\end{array}$ & $\begin{array}{l}\text { Sept. } \\
2019\end{array}$ \\
\hline \multicolumn{19}{|c|}{ Daily mean dissolved-solids concentration, in milligrams per liter } \\
\hline 1 & -- & 2,000 & 930 & 1,460 & 1,410 & 1,670 & 2,450 & 2,080 & 2,050 & 2,410 & 2,550 & 2,470 & 2,040 & 1,080 & 482 & 874 & 902 & 1,590 \\
\hline 2 & -- & 1,950 & 995 & 1,520 & 1,390 & 1,760 & 2,470 & 2,120 & 2,050 & 2,420 & 2,540 & 2,460 & 2,030 & 1,180 & 543 & 781 & 874 & 1,590 \\
\hline 3 & -- & 2,150 & 995 & 1,630 & 1,460 & 1,800 & 2,600 & 2,130 & 2,050 & 2,430 & 2,540 & 2,460 & 1,910 & 1,250 & 570 & 744 & 874 & 1,640 \\
\hline 4 & -- & 2,070 & 967 & 1,680 & 1,550 & 1,830 & 2,680 & 2,130 & 2,050 & 2,440 & 2,530 & 2,450 & 1,500 & 1,290 & 585 & 726 & 865 & 1,640 \\
\hline 5 & 1,710 & 2,020 & 967 & 1,580 & 1,690 & 1,880 & 2,670 & 2,150 & 2,060 & 2,450 & 2,530 & 2,440 & 1,060 & 1,320 & 536 & 772 & 846 & 1,610 \\
\hline 6 & 1,810 & 2,110 & 976 & 1,510 & 1,740 & 1,920 & 2,670 & 2,150 & 2,070 & 2,460 & 2,530 & 2,430 & 1,040 & 1,310 & 478 & 800 & 837 & 1,530 \\
\hline 7 & 1,890 & 2,360 & 958 & 1,420 & 1,720 & 2,050 & 2,650 & 2,160 & 2,080 & 2,470 & 2,530 & 2,420 & 948 & 1,290 & 462 & 837 & 837 & 1,400 \\
\hline 8 & 1,780 & 2,520 & 948 & 1,410 & 1,810 & 2,140 & 2,610 & 2,180 & 2,090 & 2,490 & 2,530 & 2,400 & 911 & 1,610 & 447 & 883 & 865 & 1,400 \\
\hline 9 & 1,620 & 2,600 & 1,020 & 1,380 & 1,860 & 2,180 & 2,610 & 2,190 & 2,100 & 2,500 & 2,530 & 2,380 & 828 & 1,590 & 396 & 930 & 967 & 1,330 \\
\hline 10 & 1,550 & 2,660 & 1,000 & 1,390 & 2,060 & 2,190 & 2,560 & 2,200 & 2,110 & 2,510 & 2,530 & 2,360 & 846 & 1,560 & 390 & 995 & 883 & 1,260 \\
\hline 11 & 1,570 & 2,630 & 985 & 1,400 & 2,140 & 2,230 & 2,490 & 2,200 & 2,120 & 2,520 & 2,530 & 2,340 & 985 & 1,570 & 389 & 1,070 & 865 & 1,220 \\
\hline 12 & 1,500 & 2,400 & 958 & 1,360 & 1,880 & 2,210 & 2,420 & 2,210 & 2,140 & 2,530 & 2,520 & 2,320 & 1,040 & 1,640 & 389 & 1,110 & 818 & 1,210 \\
\hline 13 & 1,700 & 2,880 & 939 & 1,300 & 1,760 & 2,230 & 2,400 & 2,220 & 2,150 & 2,530 & 2,520 & 2,300 & 1,170 & 1,700 & 420 & 1,120 & 837 & 1,230 \\
\hline 14 & 1,720 & 2,410 & 1,030 & 1,380 & 1,690 & 2,240 & 2,380 & 2,220 & 2,150 & 2,530 & 2,510 & 2,270 & 1,250 & 1,730 & 461 & 1,120 & 874 & 1,220 \\
\hline 15 & 1,720 & 2,100 & 1,130 & 1,400 & 1,710 & 2,270 & 2,330 & 2,230 & 2,170 & 2,530 & 2,510 & 2,270 & 1,250 & 1,600 & 489 & 1,100 & 930 & 1,200 \\
\hline 16 & 1,750 & 1,430 & 1,090 & 1,420 & 1,650 & 2,290 & 2,240 & 2,200 & 2,180 & 2,540 & 2,500 & 2,250 & 1,060 & 1,520 & 472 & 1,090 & 976 & 1,170 \\
\hline 17 & 1,740 & 1,310 & 1,120 & 1,470 & 1,580 & 2,320 & 2,190 & 2,180 & 2,200 & 2,540 & 2,500 & 2,240 & 948 & 1,570 & 453 & 1,110 & 1,190 & 1,160 \\
\hline 18 & 1,710 & 1,370 & 1,020 & 1,440 & 1,610 & 2,340 & 2,150 & 2,160 & 2,210 & 2,550 & 2,500 & 2,220 & 976 & 1,720 & 477 & 1,170 & 1,300 & 1,170 \\
\hline 19 & 1,590 & 1,100 & 958 & 1,450 & 1,680 & 2,350 & 2,130 & 2,150 & 2,230 & 2,550 & 2,500 & 2,210 & 985 & 1,890 & 552 & 1,160 & 1,380 & 1,170 \\
\hline 20 & 1,740 & 921 & 930 & 1,510 & 1,660 & 2,350 & 2,100 & 2,150 & 2,250 & 2,560 & 2,500 & 2,190 & 958 & 2,050 & 634 & 1,130 & 1,500 & 1,230 \\
\hline 21 & 1,870 & 1,080 & 893 & 1,580 & 1,890 & 2,350 & 2,120 & 2,120 & 2,260 & 2,560 & 2,510 & 2,170 & 921 & 2,220 & 754 & 1,130 & 1,420 & 1,250 \\
\hline 22 & 1,690 & 1,180 & 958 & 1,590 & 1,900 & 2,360 & 2,150 & 2,110 & 2,270 & 2,570 & 2,510 & 2,160 & 1,190 & 1,870 & 754 & 1,120 & 1,430 & 1,260 \\
\hline 23 & 1,650 & 1,340 & 995 & 1,620 & 1,540 & 2,370 & 2,150 & 2,090 & 2,290 & 2,570 & 2,510 & 2,150 & 1,170 & 1,150 & 687 & 1,080 & 1,480 & 1,280 \\
\hline 24 & 1,730 & 1,290 & 1,060 & 1,460 & 1,570 & 2,390 & 2,140 & 2,080 & 2,310 & 2,570 & 2,500 & 2,140 & 1,120 & 930 & 716 & 1,030 & 1,580 & 1,320 \\
\hline 25 & 1,790 & 1,180 & 1,140 & 1,400 & 1,500 & 2,400 & 2,150 & 2,070 & 2,330 & 2,580 & 2,500 & 2,130 & 1,080 & 735 & 818 & 1,040 & 1,640 & 1,330 \\
\hline 26 & 1,780 & 1,220 & 1,220 & 1,350 & 1,490 & 2,420 & 2,130 & 2,080 & 2,350 & 2,580 & 2,490 & 2,120 & 1,030 & 628 & 902 & 1,070 & 1,650 & 1,380 \\
\hline 27 & 1,890 & 911 & 1,250 & 1,370 & 1,490 & 2,430 & 2,110 & 2,070 & 2,370 & 2,580 & 2,490 & 2,110 & 976 & 536 & 930 & 1,050 & 1,700 & 1,460 \\
\hline 28 & 2,000 & 412 & 1,260 & 1,450 & 1,500 & 2,480 & 2,090 & 2,060 & 2,380 & 2,570 & 2,480 & 2,090 & 921 & 517 & 985 & 1,000 & 1,680 & 1,380 \\
\hline 29 & 2,020 & 490 & 1,330 & 1,460 & 1,530 & 2,530 & 2,070 & 2,050 & 2,390 & 2,570 & -- & 2,090 & 930 & 525 & 995 & 1,000 & 1,690 & 1,160 \\
\hline
\end{tabular}


Table 3. Daily mean dissolved-solids concentration; mean, minimum, and maximum of daily mean dissolved-solids concentration for each month during April 5 , 2018, through September 30, 2019, Blacks Fork above Smiths Fork, near Lyman, Wyoming, streamgage (09219200)._Continued

$[--$, no data $]$

\begin{tabular}{|c|c|c|c|c|c|c|c|c|c|c|c|c|c|c|c|c|c|c|}
\hline Day & $\begin{array}{l}\text { Apr. } \\
2018\end{array}$ & $\begin{array}{l}\text { May } \\
2018\end{array}$ & $\begin{array}{c}\text { June } \\
2018\end{array}$ & $\begin{array}{l}\text { July } \\
2018\end{array}$ & $\begin{array}{l}\text { Aug. } \\
2018\end{array}$ & $\begin{array}{c}\text { Sept. } \\
2018\end{array}$ & $\begin{array}{l}\text { Oct. } \\
2018\end{array}$ & $\begin{array}{l}\text { Nov. } \\
2018\end{array}$ & $\begin{array}{l}\text { Dec. } \\
2018\end{array}$ & $\begin{array}{l}\text { Jan. } \\
2019\end{array}$ & $\begin{array}{l}\text { Feb. } \\
2019\end{array}$ & $\begin{array}{l}\text { Mar. } \\
2019\end{array}$ & $\begin{array}{l}\text { Apr. } \\
2019\end{array}$ & $\begin{array}{l}\text { May } \\
2019\end{array}$ & $\begin{array}{l}\text { June } \\
2019\end{array}$ & $\begin{array}{l}\text { July } \\
2019\end{array}$ & $\begin{array}{l}\text { Aug. } \\
2019\end{array}$ & $\begin{array}{l}\text { Sept. } \\
2019\end{array}$ \\
\hline \multicolumn{19}{|c|}{ Daily mean dissolved-solids concentration, in milligrams per liter-Continued } \\
\hline 30 & 1,930 & 643 & 1,390 & 1,400 & 1,560 & 2,500 & 2,050 & 2,050 & 2,400 & 2,560 & -- & 2,080 & 902 & 450 & 939 & 948 & 1,620 & 1,120 \\
\hline 31 & -- & 818 & -- & 1,400 & 1,600 & -- & 2,060 & -- & 2,400 & 2,560 & -- & 2,060 & -- & 441 & -- & 874 & 1,570 & -- \\
\hline \multicolumn{19}{|c|}{ Mean of daily mean dissolved-solids concentration during month, in milligrams per liter } \\
\hline-- & 1,750 & 1,660 & 1,050 & 1,460 & 1,670 & 2,220 & 2,320 & 2,140 & 2,200 & 2,520 & 2,500 & 2,260 & 1,130 & 1,310 & 604 & 996 & 1,190 & 1,330 \\
\hline \multicolumn{19}{|c|}{ Minimum of daily mean dissolved-solids concentration during month, in milligrams per liter } \\
\hline-- & 1,500 & 412 & 893 & 1,300 & 1,390 & 1,670 & 2,050 & 2,050 & 2,050 & 2,410 & 2,480 & 2,060 & 828 & 441 & 389 & 726 & 818 & 1,120 \\
\hline \multicolumn{19}{|c|}{ Maximum of daily mean dissolved-solids concentration during month, in milligrams per liter } \\
\hline-- & 2,020 & 2,880 & 1,390 & 1,680 & 2,140 & 2,530 & 2,680 & 2,230 & 2,400 & 2,580 & 2,550 & 2,470 & 2,040 & 2,220 & 995 & 1,170 & 1,700 & 1,640 \\
\hline
\end{tabular}




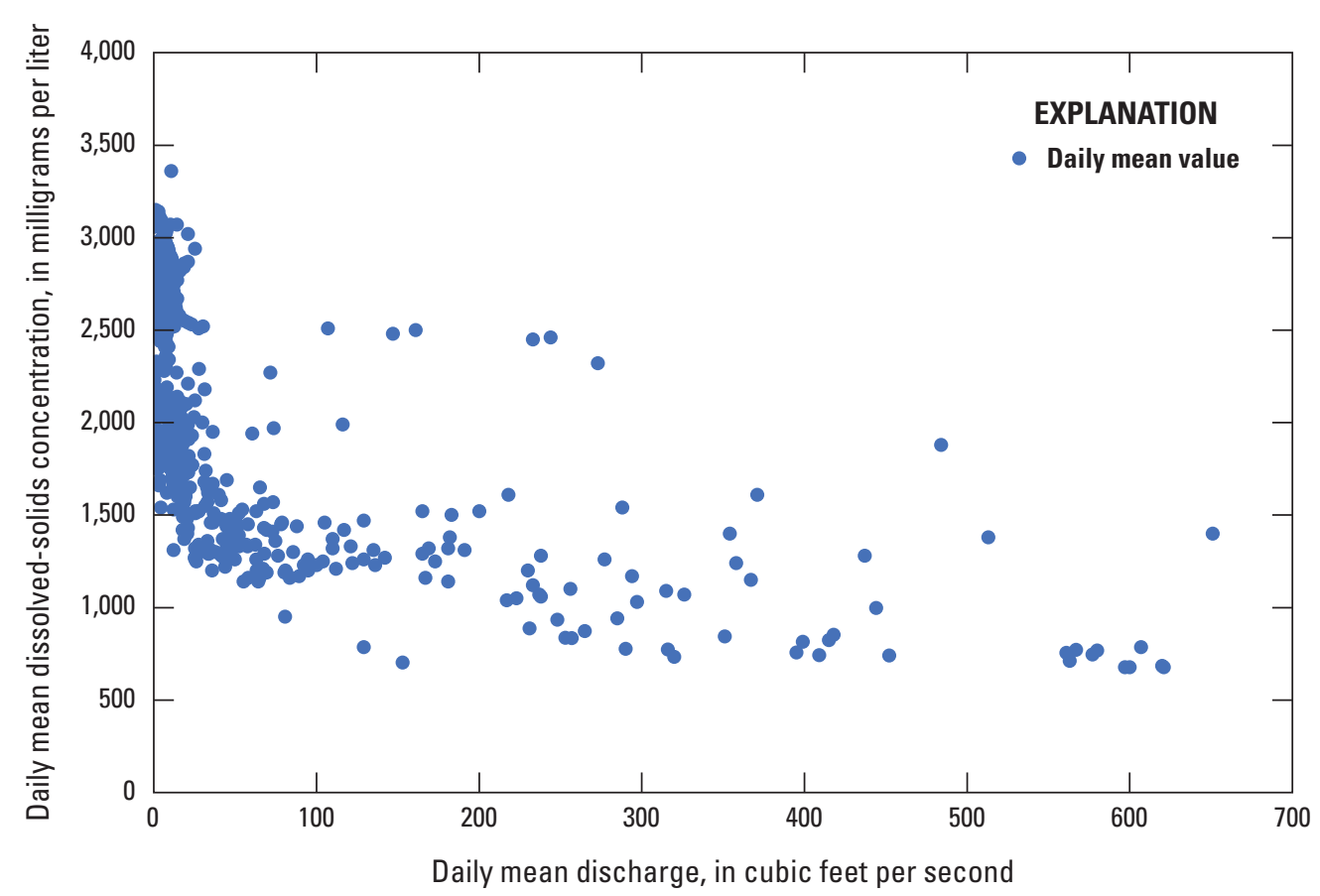

Figure 7. Relation between daily mean discharge and daily mean dissolved-solids concentration at the Blacks Fork above Smiths Fork, near Lyman, Wyoming, streamgage (09219200), April 5, 2018, through September 30, 2019.

\section{Dissolved-Solids Loads}

Daily mean discharge and daily mean dissolvedsolids concentrations were used to calculate the daily mean dissolved-solids loads. Dissolved-solids loads were calculated as the product of the discharge and dissolved-solids concentration.

The daily mean discharge and the daily mean dissolvedsolids concentration at the Blacks Fork above Smiths Fork, near Lyman, Wyo., streamgage (09219200) were highly variable during the study period (fig. 4). Although the two properties often have an inverse relation, that relation is not always observed; therefore, the daily mean dissolved-solids load (table 4) also were highly variable (figs. 3 and 4). A noticeable change occurred between early April and mid-May 2019 when the dissolved-solids load was highest at about 1,960 tons per day and dropped to 0.05 ton per day (fig. 3 , table 4 ). The large daily mean dissolved-solids load that occurs for several days in early April 2019 was a result of dissolved-solids concentrations that remained steady at higher concentrations during the same time that discharge doubled and tripled during a 2-day period (fig. 3). After 2 days of higher flows, the mean daily specific conductance decreased by about one-half, resulting in a daily mean dissolved-solids load that decreased rapidly. The higher loads resulting from sustained higher dissolvedsolids concentrations as the discharge increased may have been a function of higher discharge dissolving evaporites that formed on the stream bank and were dissolved as water levels rose. The lowest daily mean dissolved-solids load was during mid-May 2019 when discharge was low; a daily mean value of 0.05 ton per day (table 4 ).

The daily mean dissolved-solids loads during 2018 were typically lower than during 2019 . This result is primarily because the discharge was much higher in 2019 than in 2018. The mean daily discharge during April through September 2018 was $15.1 \mathrm{ft}^{3} / \mathrm{s}$ and during the same period (April through September) in 2019 was $152 \mathrm{ft} / \mathrm{s}$ - about 10 times higher than in 2018. The mean daily dissolvedsolids concentration during April through September 2018 $(1,630 \mathrm{mg} / \mathrm{L})$ was about 1.5 times higher than during the same 6 months in $2019(1,090 \mathrm{mg} / \mathrm{L})$. Therefore, although the daily mean dissolved-solids concentrations tended to be higher in 2018, the substantially higher daily mean discharges in 2019 had more of an effect on the dissolved-loads than the daily mean dissolved-solids concentrations (fig. 4).

The cumulative dissolved-solids load at the Blacks Fork above Smiths Fork, near Lyman, Wyo., streamgage (09219200) during the 18-month study was 81,200 tons, with a mean daily load of 149 tons per day (table 4). During the 6-month period from April through September 2018, the cumulative dissolved-solids load at the streamgage was estimated to be 8,740 tons and, during the same 6 months in 2019 , the cumulative dissolved-solids load was estimated to be 60,900 tons. During the fall and winter between the two periods, the cumulative dissolved-solids load was 11,600 tons (table 4). 
Table 4. Daily mean dissolved-solids load; mean, minimum, and maximum of daily mean dissolved-solids load for each month; and total monthly load during April 5, 2018, through September 30, 2019, Blacks Fork above Smiths Fork, near Lyman, Wyoming, streamgage (09219200).

$[--$, no data $]$

\begin{tabular}{|c|c|c|c|c|c|c|c|c|c|c|c|c|c|c|c|c|c|c|}
\hline Day & $\begin{array}{l}\text { Apr. } \\
2018\end{array}$ & $\begin{array}{l}\text { May } \\
2018\end{array}$ & $\begin{array}{c}\text { June } \\
2018 \\
\end{array}$ & $\begin{array}{l}\text { July } \\
2018\end{array}$ & $\begin{array}{l}\text { Aug. } \\
2018\end{array}$ & $\begin{array}{l}\text { Sept. } \\
2018\end{array}$ & $\begin{array}{c}\text { Oct. } \\
2018\end{array}$ & $\begin{array}{l}\text { Nov. } \\
2018 \\
\end{array}$ & $\begin{array}{l}\text { Dec. } \\
2018\end{array}$ & $\begin{array}{l}\text { Jan. } \\
2019\end{array}$ & $\begin{array}{l}\text { Feb. } \\
2019\end{array}$ & $\begin{array}{l}\text { Mar. } \\
2019 \\
\end{array}$ & $\begin{array}{l}\text { Apr. } \\
2019 \\
\end{array}$ & $\begin{array}{l}\text { May } \\
2019\end{array}$ & $\begin{array}{l}\text { June } \\
2019 \\
\end{array}$ & $\begin{array}{l}\text { July } \\
2019\end{array}$ & $\begin{array}{l}\text { Aug. } \\
2019\end{array}$ & $\begin{array}{l}\text { Sept. } \\
2019\end{array}$ \\
\hline \multicolumn{19}{|c|}{ Daily mean dissolved-solids load, in tons per day } \\
\hline 1 & -- & 48.6 & 110 & 13.0 & 83.0 & 0.59 & 3.11 & 37.6 & 32.4 & 36.6 & 43.5 & 60.3 & 1,340 & 202 & 377 & 542 & 243 & 44.1 \\
\hline 2 & -- & 38.8 & 120 & 6.49 & 48.5 & 0.10 & 2.60 & 44.3 & 36.8 & 38.2 & 40.6 & 61.7 & 1,280 & 173 & 514 & 539 & 224 & 49.3 \\
\hline 3 & -- & 36.7 & 140 & 4.45 & 24.9 & 1.02 & 4.70 & 45.2 & 41.0 & 40.9 & 37.0 & 64.2 & 1,410 & 135 & 407 & 478 & 191 & 51.9 \\
\hline 4 & -- & 31.9 & 123 & 2.86 & 25.2 & 2.07 & 6.66 & 43.9 & 41.9 & 41.1 & 34.9 & 67.4 & 1,960 & 114 & 364 & 425 & 190 & 74.5 \\
\hline 5 & 91.7 & 21.1 & 98.6 & 4.05 & 6.20 & 2.33 & 20.9 & 46.2 & 43.5 & 40.5 & 34.5 & 71.1 & 1,860 & 110 & 371 & 656 & 204 & 90.6 \\
\hline 6 & 102 & 7.11 & 91.9 & 7.72 & 0.37 & 7.83 & 15.4 & 44.6 & 46.3 & 40.5 & 33.5 & 72.2 & 1,440 & 128 & 407 & 503 & 189 & 88.5 \\
\hline 7 & 141 & 4.52 & 87.0 & 5.98 & 0.93 & 4.37 & 26.0 & 41.7 & 47.9 & 42.2 & 30.1 & 73.9 & 1,120 & 227 & 492 & 377 & 147 & 89.7 \\
\hline 8 & 150 & 3.19 & 106 & 8.84 & 0.15 & 1.56 & 72.5 & 63.6 & 48.5 & 42.9 & 33.9 & 74.6 & 880 & 503 & 545 & 267 & 162 & 88.9 \\
\hline 9 & 130 & 2.52 & 90.5 & 8.96 & 0.15 & 2.88 & 99.2 & 69.1 & 49.6 & 43.5 & 39.0 & 74.4 & 819 & 315 & 663 & 158 & 223 & 161 \\
\hline 10 & 98.3 & 3.44 & 74.5 & 45.9 & 7.39 & 0.95 & 144 & 67.1 & 50.7 & 44.0 & 44.1 & 74.4 & 671 & 254 & 653 & 155 & 160 & 113 \\
\hline 11 & 88.1 & 34.7 & 67.2 & 56.0 & 80.6 & 0.84 & 169 & 23.2 & 51.3 & 44.2 & 47.5 & 73.8 & 481 & 153 & 629 & 210 & 187 & 240 \\
\hline 12 & 71.4 & 85.6 & 69.5 & 56.7 & 32.3 & 0.77 & 137 & 31.0 & 51.0 & 43.7 & 49.4 & 74.5 & 511 & 110 & 626 & 233 & 142 & 220 \\
\hline 13 & 78.8 & 82.3 & 63.3 & 45.3 & 30.8 & 0.12 & 120 & 21.7 & 50.7 & 40.5 & 50.4 & 75.1 & 632 & 80.2 & 638 & 237 & 131 & 137 \\
\hline 14 & 77.4 & 121 & 52.0 & 37.7 & 27.4 & 0.30 & 103 & 28.1 & 50.8 & 39.0 & 48.9 & 74.8 & 738 & 118 & 698 & 316 & 84.2 & 108 \\
\hline 15 & 68.1 & 171 & 62.4 & 39.3 & 60.8 & 0.98 & 89.9 & 29.7 & 48.2 & 38.4 & 47.2 & 75.8 & 1,260 & 83.2 & 801 & 260 & 63.7 & 102 \\
\hline 16 & 67.3 & 69.5 & 61.6 & 37.6 & 46.4 & 2.85 & 86.3 & 27.6 & 43.5 & 38.1 & 46.1 & 76.4 & 1,010 & 49.3 & 739 & 198 & 31.9 & 87.2 \\
\hline 17 & 59.0 & 42.0 & 105 & 36.3 & 1.70 & 4.63 & 69.1 & 28.0 & 40.4 & 39.5 & 45.5 & 77.2 & 609 & 13.6 & 705 & 173 & 13.8 & 79.9 \\
\hline 18 & 59.5 & 58.2 & 206 & 20.3 & 0.13 & 2.84 & 71.7 & 26.7 & 39.9 & 42.8 & 45.3 & 77.2 & 503 & 0.05 & 729 & 199 & 10.6 & 80.5 \\
\hline 19 & 58.7 & 132 & 175 & 8.91 & 1.04 & 1.08 & 71.7 & 22.4 & 35.8 & 45.6 & 46.3 & 78.1 & 449 & 0.05 & 622 & 164 & 7.77 & 87.2 \\
\hline 20 & 54.8 & 65.0 & 125 & 4.53 & 10.9 & 0.19 & 70.7 & 18.7 & 32.0 & 46.8 & 47.6 & 79.8 & 426 & 0.11 & 487 & 126 & 28.6 & 61.2 \\
\hline 21 & 70.0 & 51.2 & 105 & 2.77 & 31.1 & 1.14 & 67.9 & 17.1 & 33.4 & 47.8 & 49.0 & 81.5 & 429 & 37.6 & 482 & 143 & 41.8 & 65.5 \\
\hline 22 & 75.2 & 38.8 & 86.5 & 5.14 & 38.0 & 5.47 & 63.9 & 18.0 & 36.7 & 49.6 & 50.4 & 83.4 & 924 & 361 & 662 & 153 & 32.8 & 65.8 \\
\hline 23 & 51.3 & 40.1 & 73.2 & 88.9 & 46.2 & 14.8 & 61.0 & 20.4 & 36.7 & 51.4 & 52.7 & 90.6 & 521 & 569 & 822 & 148 & 49.4 & 66.1 \\
\hline 24 & 34.7 & 77.0 & 58.9 & 122 & 28.0 & 34.2 & 58.2 & 21.3 & 41.5 & 52.3 & 55.2 & 96.8 & 391 & 695 & 574 & 118 & 31.5 & 53.7 \\
\hline 25 & 38.7 & 57.0 & 54.9 & 80.2 & 26.9 & 35.0 & 54.6 & 22.8 & 43.2 & 52.3 & 56.5 & 107 & 340 & 442 & 400 & 139 & 30.1 & 55.2 \\
\hline 26 & 33.0 & 61.4 & 57.5 & 65.8 & 10.2 & 6.40 & 51.2 & 26.4 & 44.2 & 50.3 & 58.2 & 121 & 306 & 420 & 331 & 134 & 14.6 & 46.7 \\
\hline 27 & 28.3 & 300 & 48.7 & 78.1 & 1.00 & 11.7 & 51.5 & 30.7 & 43.1 & 48.4 & 59.7 & 132 & 355 & 366 & 323 & 148 & 35.5 & 31.0 \\
\hline 28 & 36.0 & 170 & 27.5 & 83.6 & 0.16 & 11.0 & 48.7 & 31.5 & 43.8 & 46.5 & 59.9 & 155 & 258 & 556 & 292 & 154 & 59.8 & 118 \\
\hline 29 & 42.4 & 170 & 14.0 & 60.6 & 3.18 & 17.6 & 41.9 & 28.8 & 47.0 & 47.0 & -- & 603 & 237 & 588 & 325 & 169 & 77.0 & 116 \\
\hline
\end{tabular}


Table 4. Daily mean dissolved-solids load; mean, minimum, and maximum of daily mean dissolved-solids load for each month; and total monthly load during April 5, 2018, through September 30, 2019, Blacks Fork above Smiths Fork, near Lyman, Wyoming, streamgage (09219200).-Continued

$[--$, no data $]$

\begin{tabular}{|c|c|c|c|c|c|c|c|c|c|c|c|c|c|c|c|c|c|c|}
\hline Day & $\begin{array}{l}\text { Apr. } \\
2018 \\
\end{array}$ & $\begin{array}{l}\text { May } \\
2018\end{array}$ & $\begin{array}{l}\text { June } \\
2018 \\
\end{array}$ & $\begin{array}{l}\text { July } \\
2018 \\
\end{array}$ & $\begin{array}{l}\text { Aug. } \\
2018\end{array}$ & $\begin{array}{l}\text { Sept. } \\
2018\end{array}$ & $\begin{array}{l}\text { Oct. } \\
2018\end{array}$ & $\begin{array}{l}\text { Nov. } \\
2018\end{array}$ & $\begin{array}{l}\text { Dec. } \\
2018 \\
\end{array}$ & $\begin{array}{l}\text { Jan. } \\
2019 \\
\end{array}$ & $\begin{array}{l}\text { Feb. } \\
2019\end{array}$ & $\begin{array}{l}\text { Mar. } \\
2019\end{array}$ & $\begin{array}{l}\text { Apr. } \\
2019 \\
\end{array}$ & $\begin{array}{l}\text { May } \\
2019\end{array}$ & $\begin{array}{l}\text { June } \\
2019 \\
\end{array}$ & $\begin{array}{l}\text { July } \\
2019 \\
\end{array}$ & $\begin{array}{l}\text { Aug. } \\
2019\end{array}$ & $\begin{array}{l}\text { Sept. } \\
2019\end{array}$ \\
\hline \multicolumn{19}{|c|}{ Daily mean dissolved-solids load, in tons per day-Continued } \\
\hline 30 & 48.4 & 140 & 12.7 & 53.0 & 2.82 & 15.0 & 36.3 & 27.3 & 46.5 & 47.5 & -- & 903 & 225 & 497 & 360 & 195 & 81.5 & 110 \\
\hline 31 & -- & 122 & -- & 69.6 & 0.60 & -- & 34.5 & -- & 40.9 & 45.8 & -- & 817 & -- & 380 & -- & 149 & 67.7 & -- \\
\hline \multicolumn{19}{|c|}{ Mean of daily mean dissolved-solids load during month, in tons per day } \\
\hline-- & 71.3 & 73.8 & 85.6 & 37.4 & 21.8 & 6.35 & 63.0 & 33.5 & 43.2 & 44.1 & 46.0 & 150 & 780 & 248 & 535 & 254 & 102 & 92.7 \\
\hline \multicolumn{19}{|c|}{ Minimum of daily mean dissolved-solids load during month, in tons per day } \\
\hline-- & 28.3 & 2.52 & 12.7 & 2.77 & 0.13 & 0.10 & 2.60 & 17.1 & 32.0 & 36.6 & 30.1 & 60.3 & 225 & 0.05 & 292 & 118 & 7.77 & 31.0 \\
\hline \multicolumn{19}{|c|}{ Maximum of daily mean dissolved-solids load during month, in tons per day } \\
\hline-- & 150 & 300 & 206 & 122 & 83.0 & 35.0 & 169 & 69.1 & 51.3 & 52.3 & 59.9 & 903 & 1,960 & 695 & 822 & 656 & 243 & 240 \\
\hline \multicolumn{19}{|c|}{ Dissolved-solids load during month, in tons } \\
\hline-- & 1,850 & 2,290 & 2,570 & 1,160 & 677 & 190 & 1,950 & 1,000 & 1,340 & 1,370 & 1,290 & 4,650 & 23,400 & 7,680 & 16,000 & 7,860 & 3,150 & 2,780 \\
\hline
\end{tabular}




\section{Synoptic Sampling}

Synoptic or "snapshot" sampling, where discharge measurements and surface-water samples are collected from several sites along a reach during a short period (typically within about 24 hours), was used to describe changes in the discharge and water quality of Blacks Fork at several sites during 1 or 2 days. This type of sampling is often used to study changes in stream chemistry because of environmental or anthropogenic factors (Shope and Gerner, 2014), typically when groundwater contributions dominate streamflow. The many diversions and return flows in the basin limit the use of synoptic discharge measurements to calculate specific groundwater gains or losses (a water balance) or specific salinity loading from groundwater or irrigation returns. However, the synoptic sampling on Blacks Fork can be used to describe the general conditions of Blacks Fork, that is discharge and dissolvedsolids concentrations at different locations and how conditions change downstream. In order for the synoptic measurements to best represent conditions when upstream inflows from surface water were minimal starting at site BF7 (fig. 1), an effort was made to complete the synoptic sampling during periods when the previous days did not receive rain. This effort was not always possible, and the September 2019 sampling was influenced by rain during the previous day; about 0.75 inch was recorded during that period at the Mountain View weather station (NOAA Regional Climate Centers, 2020).

Seven sites were selected for the synoptic sampling of Blacks Fork above Smiths Fork (fig. 8, table 5), with the most upstream site (BF11) at the outlet of Meeks Cabin Reservoir (figs. 1 and 8) and the most downstream site at the streamgage Blacks Fork above Smiths Fork, near Lyman, Wyo., (09219200) (BF3, table 5, fig. 8). Instantaneous discharge measurement, specific conductance reading, and dissolvedsolids samples were collected at all sites. Synoptic sampling occurred during months when irrigation diversions and return flows were considered likely to occur (planned to be in July, August, and September of 2018 and in June, July, August, and September of 2019). Of the seven sites, six sites were on the main stem of the Blacks Fork (fig. 1), and one site, Threemile Creek (site TM1), was a tributary. A study by the Natural Resources Conservation Service (2006) determined that much of the flow in Threemile Creek is return flow from seeps, springs, and overland flow from irrigation.

\section{Discharge}

Instantaneous discharge measurements were recorded at each of the seven synoptic sampling sites (table 5), either from a measurement (or estimate) made at the time of sample collection or by retrieving the data from the streamgage record (U.S. Geological Survey, 2021a). The most upstream site (Blacks Fork near Millburne, Wyo., streamgage [09218500], site BF11) and the most downstream site (Blacks Fork above Smiths Fork, near Lyman, Wyo., streamgage [09219200], site $\mathrm{BF} 3$ ) had continuous discharge during the time of the synoptic sampling (site BF11 is a seasonally operated streamgage). The daily mean discharge at these two sites and instantaneous discharge during each synoptic sampling are shown in figure 9.

During the synoptic sampling events, site BF11 had the highest measured discharge among the sites and had the most variability among the events, with discharge ranging from 47.1 to $950 \mathrm{ft}^{3} / \mathrm{s}$ (fig. 10, table 5). Discharge measured at the other six sites tended to be more consistent throughout the year, with the exception of June 2019 (fig. 10). Main-stem discharge decreased within the upper reach between sites BF11 and BF7 as a result of diversions from the river between the two sites (figs. 1 and 11). Downstream from Threemile Creek (site TM1), discharge values were similar among sites. The highest median discharge downstream from Threemile Creek (site TM1) was at the most downstream site (BF3).

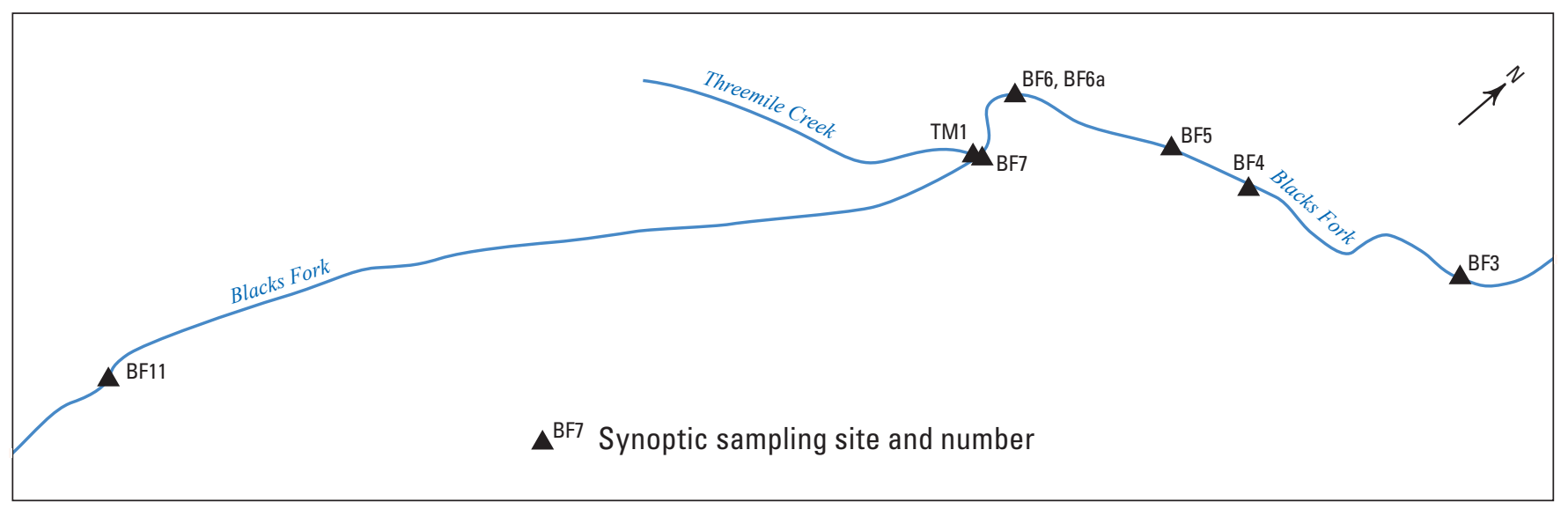

Not to scale

Figure 8. Schematic of synoptic sampling sites on Blacks Fork and Threemile Creek, sampled during July, August, and September 2018 and June, July, August, and September 2019. 
Table 5. Discharge, specific conductance, dissolved-solids concentration, and dissolved-solids load from samples collected from synoptic sampling sites on Blacks Fork and Threemile Creek, sampled during July, August, and September 2018 and June, July, August, and September 2019.

[ $\mathrm{ft} 3 / \mathrm{s}$, cubic foot per second; $\mu \mathrm{S} / \mathrm{cm}$ at $25^{\circ} \mathrm{C}$, microsiemens per centimeter at 25 degrees Celsius; $\mathrm{mg} / \mathrm{L}$, milligram per liter; ton/d, ton per day; NA, not applicable; E, estimated value]

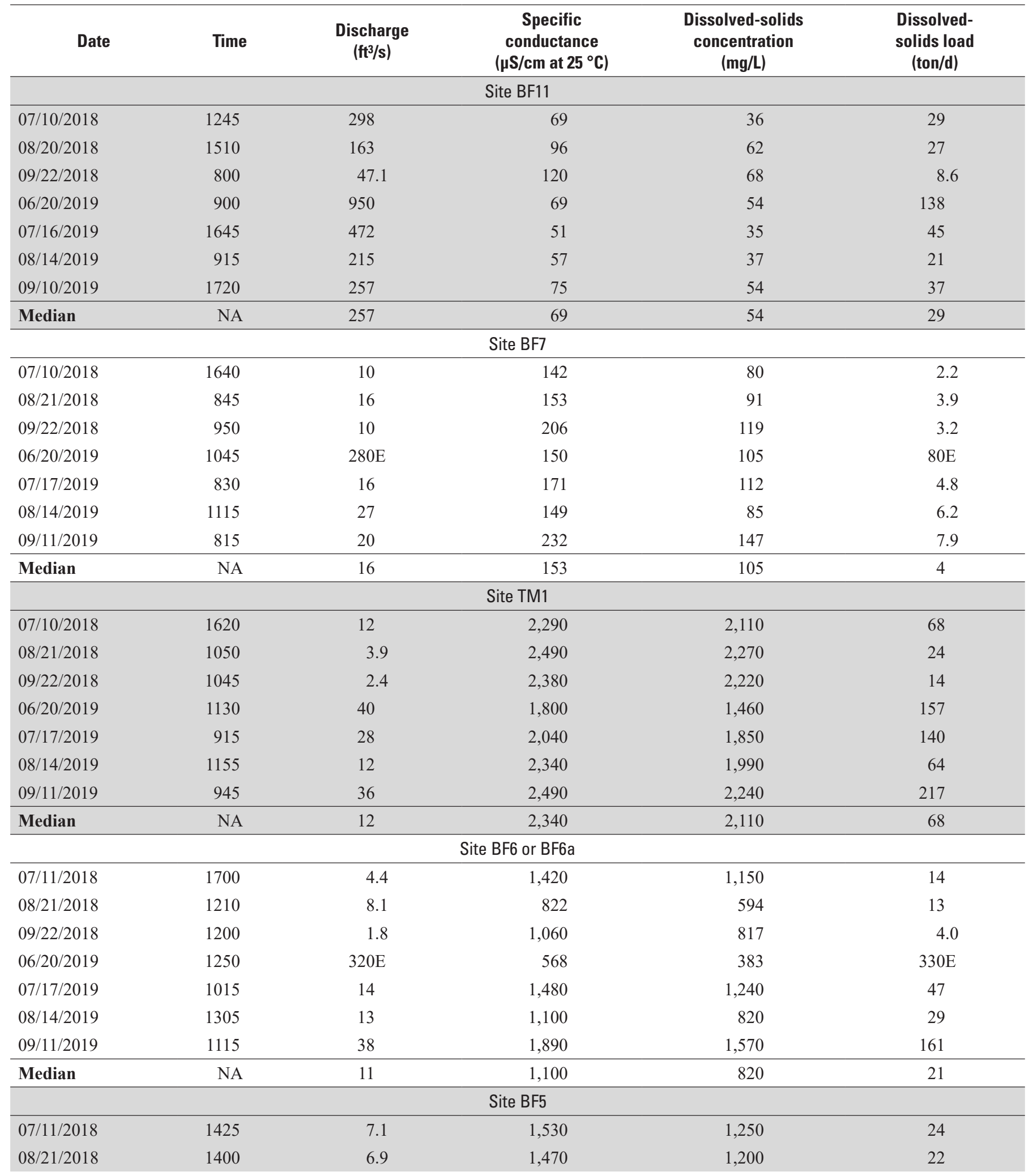


Table 5. Discharge, specific conductance, dissolved-solids concentration, and dissolved-solids load from samples collected from synoptic sampling sites on Blacks Fork and Threemile Creek, sampled during July, August, and September 2018 and June, July, August, and September 2019.-Continued

[ft $3 / \mathrm{s}$, cubic foot per second; $\mu \mathrm{S} / \mathrm{cm}$ at $25^{\circ} \mathrm{C}$, microsiemens per centimeter at 25 degrees Celsius; $\mathrm{mg} / \mathrm{L}$, milligram per liter; ton/d, ton per day; NA, not applicable; E, estimated value]

\begin{tabular}{|c|c|c|c|c|c|}
\hline Date & Time & $\begin{array}{c}\text { Discharge } \\
\left(\mathrm{ft}^{3} / \mathbf{s}\right)\end{array}$ & $\begin{array}{c}\text { Specific } \\
\text { conductance } \\
\left(\mu \mathrm{S} / \mathrm{cm} \text { at } 25^{\circ} \mathrm{C}\right)\end{array}$ & $\begin{array}{l}\text { Dissolved-solids } \\
\text { concentration } \\
(\mathrm{mg} / \mathrm{L})\end{array}$ & $\begin{array}{c}\text { Dissolved- } \\
\text { solids load } \\
\text { (ton/d) }\end{array}$ \\
\hline \multicolumn{6}{|c|}{ Site BF5-Continued } \\
\hline $09 / 22 / 2018$ & 1315 & 1.6 & 2,050 & 1,770 & 7.6 \\
\hline 06/20/2019 & 1340 & $300 \mathrm{E}$ & 634 & 449 & $360 \mathrm{E}$ \\
\hline 07/17/2019 & 1130 & 24 & 1,400 & 1,090 & 71 \\
\hline 08/14/2019 & 1420 & 16 & 1,200 & 873 & 38 \\
\hline 09/11/2019 & 1240 & 52 & 1,390 & 1,080 & 151 \\
\hline Median & NA & 12 & 1,400 & 1,090 & 31 \\
\hline \multicolumn{6}{|c|}{ Site BF4 } \\
\hline $07 / 11 / 2018$ & 1230 & 11 & 1,890 & 1,580 & 47 \\
\hline $08 / 21 / 2018$ & 1550 & 9.2 & 1,900 & 1,610 & 40 \\
\hline $09 / 22 / 2018$ & 1505 & 2.7 & 2,630 & 2,370 & 17 \\
\hline 06/20/2019 & 1510 & $315 \mathrm{E}$ & 674 & 482 & $400 \mathrm{E}$ \\
\hline 07/17/2019 & 1245 & 27 & 603 & 1,300 & 95 \\
\hline 08/14/2019 & 1540 & 19 & 1,360 & 1,050 & 54 \\
\hline 09/11/2019 & 1410 & 42 & 1,570 & 1,250 & 142 \\
\hline Median & NA & 15 & 1,570 & 1,300 & 50 \\
\hline \multicolumn{6}{|c|}{ Site BF3 } \\
\hline $07 / 10 / 2018$ & 1745 & 20 & 1,840 & 1,430 & 77 \\
\hline $08 / 21 / 2018$ & 1710 & 5.9 & 3,020 & 2,510 & 40 \\
\hline $09 / 22 / 2018$ & 1615 & 1.1 & 3,270 & 2,720 & 8.1 \\
\hline 06/20/2019 & 1645 & 272 & 888 & 629 & 461 \\
\hline 07/17/2019 & 1430 & 63 & 1,490 & 1,140 & 194 \\
\hline 08/14/2019 & 1725 & 34 & 1,240 & 897 & 82 \\
\hline 09/11/2019 & 1350 & 78 & 1,910 & 1,450 & 305 \\
\hline Median & NA & 34 & 1,840 & 1,430 & 82 \\
\hline
\end{tabular}

Melting snowpack resulted in higher flows during June 2019 (fig. 11). Discharge was higher at all sites during June 2019 than during other months, but was similar among main-stem Blacks Fork sites (from BF7 downstream to BF3) during the same period. The differences in discharge among main-stem Blacks Fork sites, including and downstream from BF7, were within the measurement or estimation error associated with each value. Discharge during June 2019 can be seen as the outlier values in figure 10 .
Before the synoptic sampling in September 2019, precipitation fell over the basin. Runoff from the precipitation can be seen in the increased discharge at the streamgages Blacks Fork near Millburne, Wyo. (09218500, site BF11) and Blacks Fork above Smiths Fork, near Lyman, Wyo. (09219200, site BF3) (fig. 9). The runoff is assumed to have caused an increase in discharge, to an unknown degree, at all sites. 


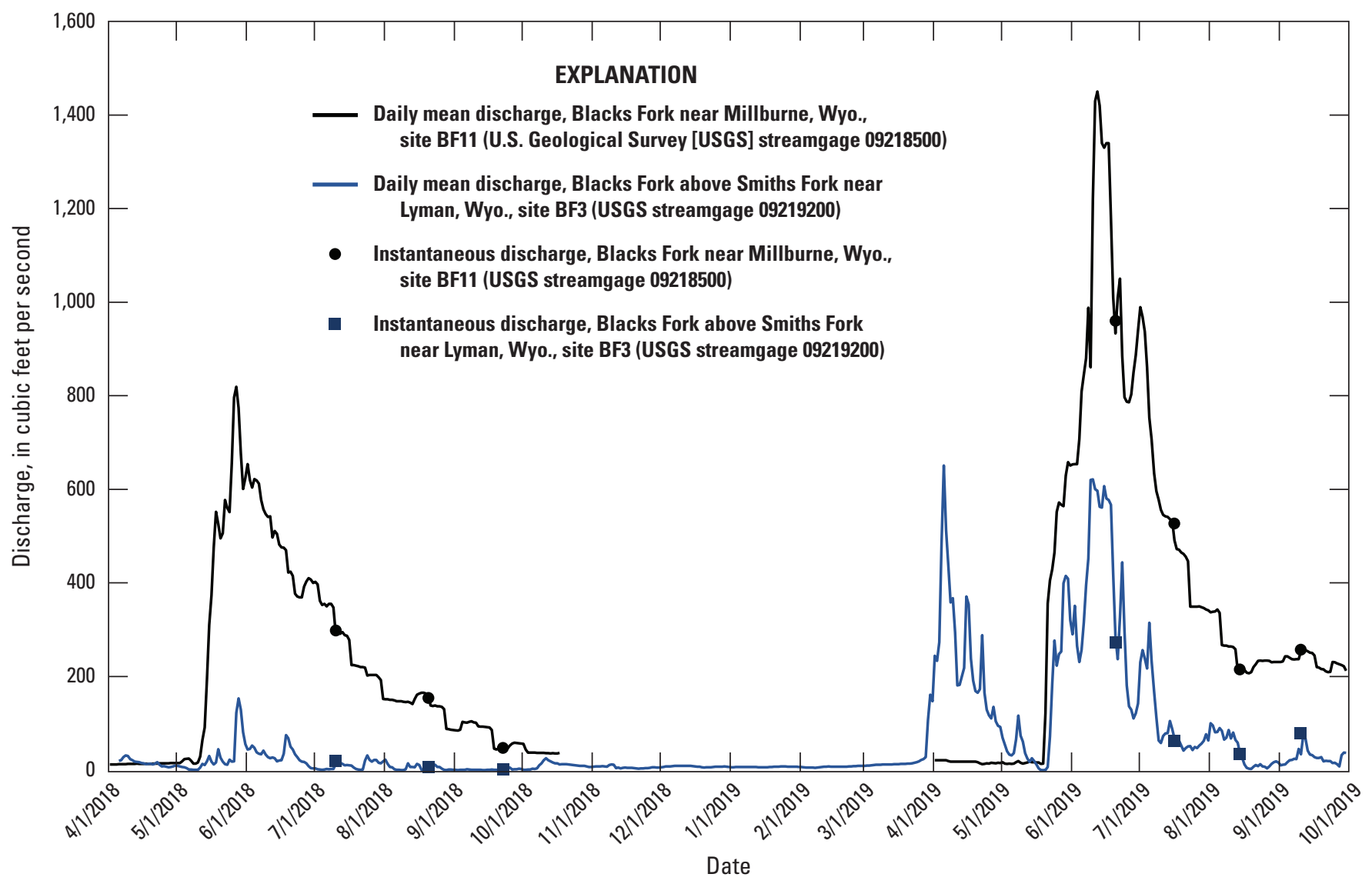

Figure 9. Daily mean discharge at the Blacks Fork near Millburne, Wyoming, and Blacks Fork above Smiths Fork, near Lyman, Wyoming, streamgage and instantaneous discharge measurements during 2018 and 2019 synoptic sampling.

\section{Dissolved-Solids Concentrations}

Water-quality samples were collected and analyzed for dissolved-solids concentration at each site during the seven synoptic sampling events. Results indicated that dissolvedsolids concentrations were variable from site to site, and concentrations were variable among synoptic sampling events at the downstream sites (BF6, BF5, BF4, and BF3) (fig. 12). The two most upstream sites, BF11 and BF7 (fig. 8) had the lowest dissolved-solids concentrations among all sites during the seven sampling events. Dissolved-solids concentrations were less variable at sites BF11 and BF7 when compared to other sites. Sites downstream from site BF7 had larger dissolved-solids concentrations as well as more variability in dissolved-solids concentrations among synoptics sampling events. Site BF3 had the largest range of dissolved-solids concentrations (629 to $2,720 \mathrm{mg} / \mathrm{L}$ ) and the largest dissolvedsolids concentration of any site sampled. Site TM1 had the largest median dissolved-solids concentration of $2,110 \mathrm{mg} / \mathrm{L}$ (table 5) and was the only site where all dissolved-solids concentrations during the synoptic sampling events were above $1,800 \mathrm{mg} / \mathrm{L}$. Starting at site BF6, the general tendency was an increase in dissolved-solids concentration in a downstream direction, with the median value increasing (table 5; figs. 10 and 12), as well as the largest dissolved-solids concentration at the site increasing. Site BF3 had the largest median dissolved-solids concentration of any main-stem site $(1,430 \mathrm{mg} / \mathrm{L}$; fig. 10 , table 5).

During the higher flows of June 2019, the dissolvedsolids concentrations were much lower compared to the other synoptic sampling periods because of the large amount of dilute water entering the stream. During 2018, dissolved-solids concentrations generally increased at each downstream site, starting at site BF7. During 2019, dissolved-solids concentration at main-stem Blacks Fork sites downstream from site BF7 tended to have similar dissolved-solids concentrations during each synoptic sampling event (fig. 12), although concentrations among synoptic sampling events varied greatly. The decrease of dissolved-solids concentration between sites BF6 and BF5 during September 2019 was likely the result of the increased runoff from precipitation (figs. 11 and 12). 

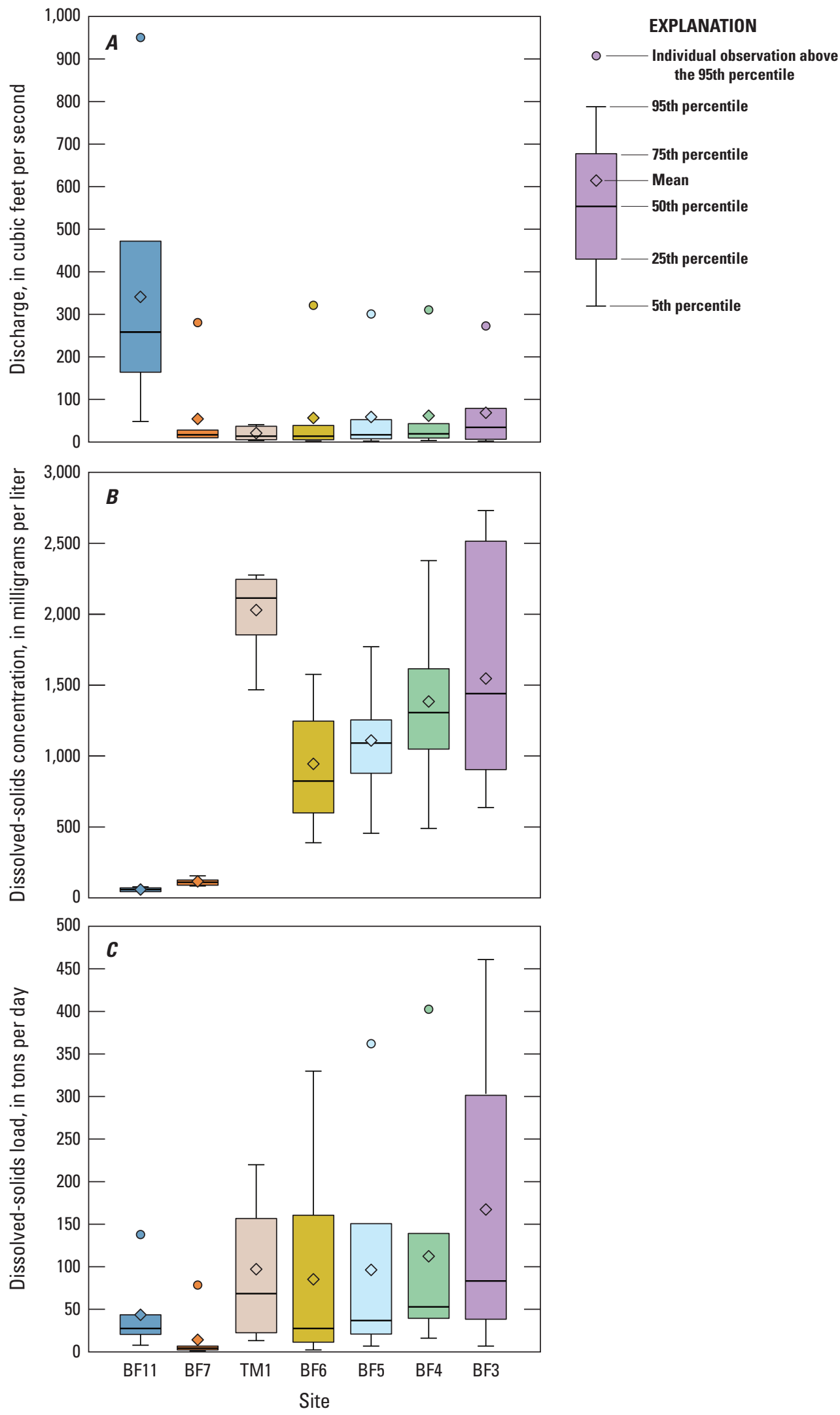

Figure 10. Box plots showing results from instantaneous samples collected on the Blacks Fork and Threemile Creek sites during the three synoptic sampling events in 2018 and the four synoptic events in 2019. $A$, discharge; $B$, dissolved-solids concentration; and $C$, dissolved-solids load. Sites are arranged from left to right in downstream order. 


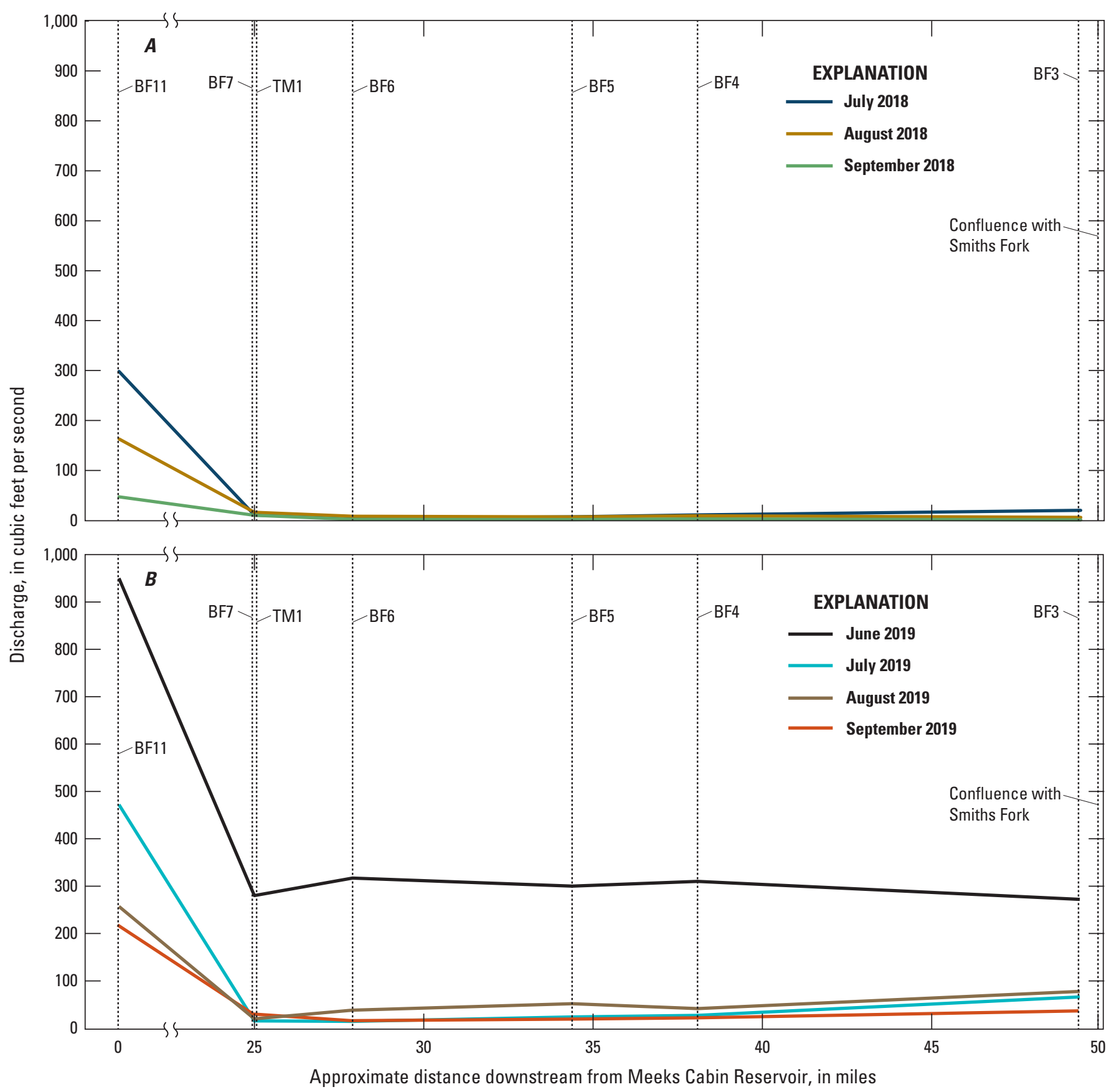

Figure 11. Discharge at main-stem Blacks Fork and tributary Threemile Creek sites during seven synoptic sampling events. $A$, July, August, and September 2018 and B, June, July, August, and September 2019.

\section{Dissolved-Solids Loads}

Dissolved-solids loads were calculated for each site using discharge and dissolved-solids concentrations from each of the seven synoptic sampling events (table 5, fig. 13). Site BF7 had the smallest median and smallest variability in dissolved-solids loads. Site BF7 had dissolved-solids concentrations more similar to the upper BF11 site than the other sites, but much smaller discharges than site BF11 (fig. 10), thereby resulting in smaller dissolved-solids loads (figs. 9 and 13). The site with the largest mean and largest variability in dissolved-solids loads was site BF3. The mean dissolved-solids loads of the tributary site, TM1, tended to be similar to the main-stem sites BF6, BF5, and BF4 (figs. 10 and 13), as was the amount of variability among samples at each site. The mean instantaneous dissolved-solids load for sites TM1, BF6, BF5, and BF4 during all seven synoptic sampling events was about 100 tons per day. The mean and variability of dissolved-solids load at site BF3 during the synoptic sampling events was larger, and the mean dissolved-solids load was more than 150 tons per day (fig. 10). 


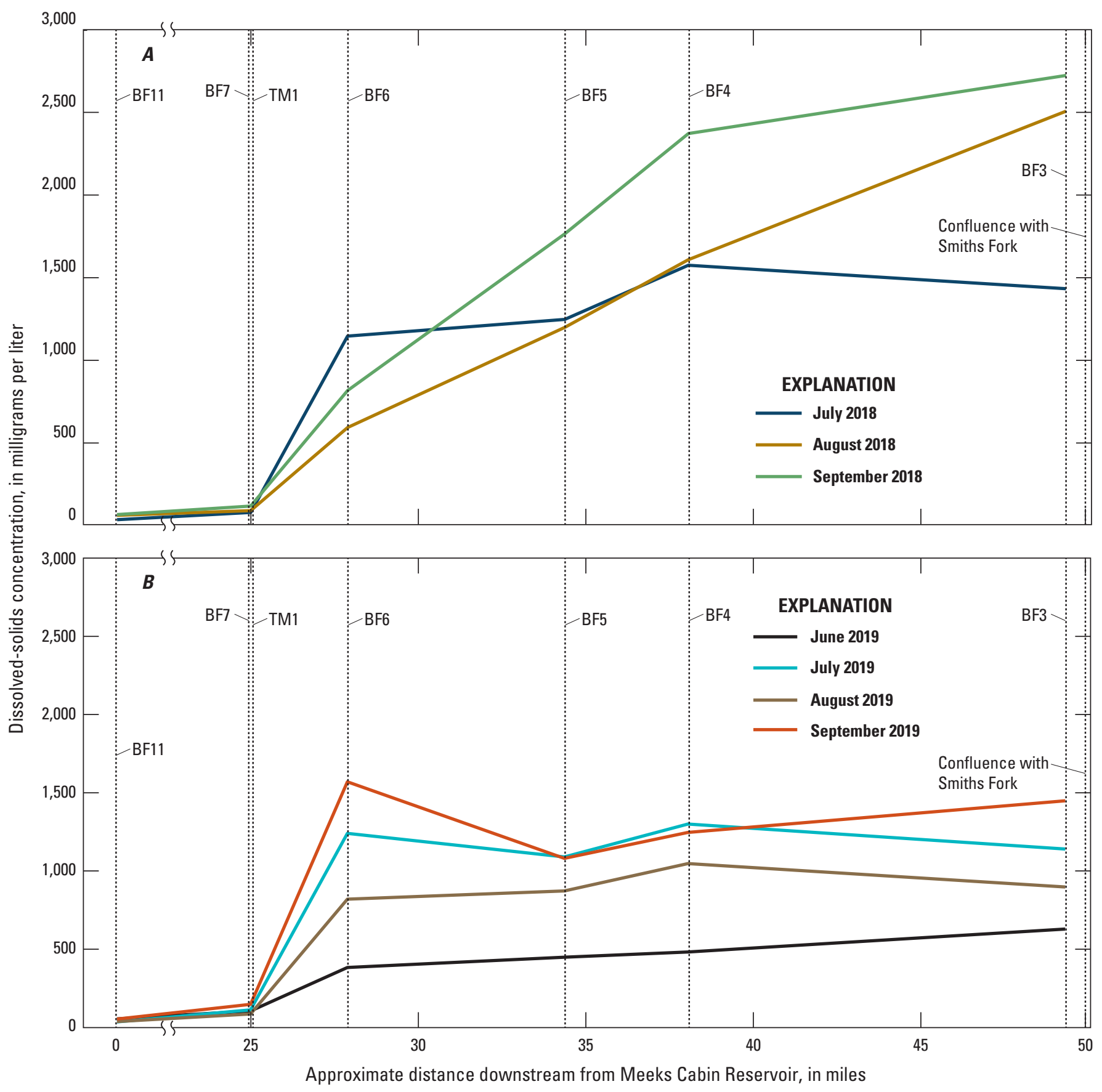

Figure 12. Dissolved-solids concentrations of samples collected from main-stem Blacks Fork and tributary Threemile Creek sites during seven synoptic sampling events. A, July, August, and September 2018 and B, June, July, August, and September 2019.

Changes in the dissolved-solids load among sites during most synoptic sampling events presented a general pattern of decreasing dissolved-solids loads between sites BF11 and BF7. This pattern was because of the diversion of dilute water, then increasing dissolved-solids loads downstream from site BF7 to site BF3 (fig. 13, table 5). This increase is likely due to a combination of direct return flows and groundwater discharge (with higher dissolved-solids concentrations [Sunrise Engineering, 2013]) into the stream. Although the range of values of the dissolved-solids loads at the seven sites were still reasonably large during the course of the study, the values and amount variability in loads tended to be more similar among sites than dissolved-solids concentrations (fig. 10). Dissolvedsolids loads during 2018 were much smaller than loads during 2019, in particular at sites downstream from site BF11, primarily because discharges were higher in 2019 (fig. 13). Dissolved-solids concentrations were only somewhat lower in 2019 , leading to a higher calculated dissolved-solids load in 2019 because of higher discharges (figs. 12 and 13). 


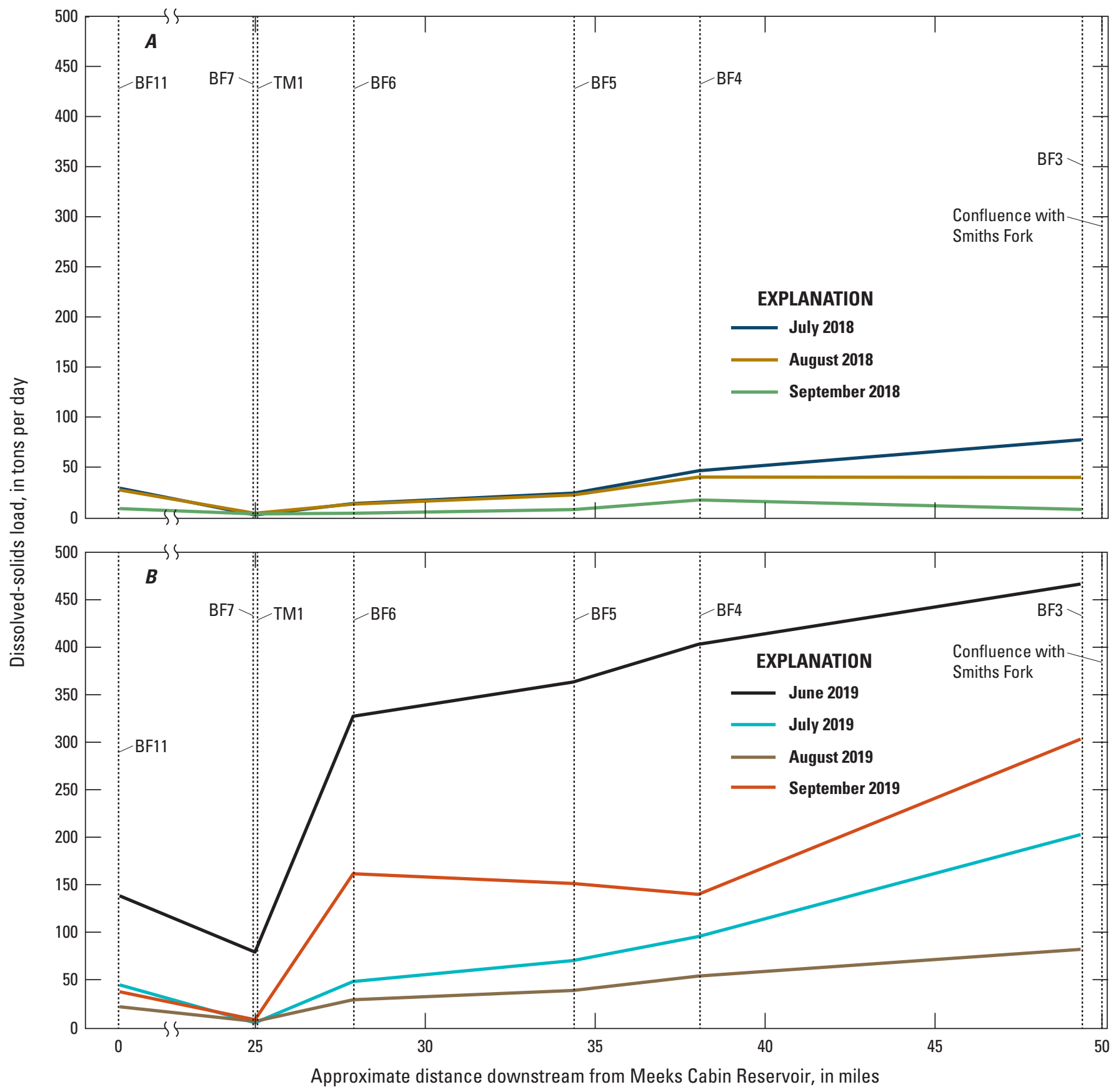

Figure 13. Dissolved-solids loads at main-stem Blacks Fork and tributary Threemile Creek sites during seven synoptic sampling events. A, July, August, and September 2018 and B, June, July, August, and September 2019. 


\section{Summary}

The Colorado River Basin Salinity Control Forum was formed in 1973 to coordinate salinity control efforts among the States in the Colorado River Basin, including Wyoming. The Colorado River Salinity Control Act of 1974 (Public Law 93-320) authorized "the construction, operation, and maintenance of certain works in the Colorado River Basin to control the salinity of water delivered to users in the United States and Mexico." Water-quality standards for salinity in the lower Colorado River Basin were adopted in 1975. To help meet these standards, the Bureau of Reclamation, Natural Resource Conservation Service, and States within the Colorado River Basin have implemented salinity control projects that focus on reducing salt loading associated with irrigated agriculture by improving water delivery systems and water management practices. The term salinity is synonymous with dissolvedsolids concentration in this report.

The Bureau of Reclamation, in conjunction with the Colorado River Basin Salinity Control Forum, was interested in determining the contribution of dissolved solids from Blacks Fork above Smiths Fork to the Colorado River and initiated a study of Blacks Fork above Smiths Fork in 2018. In early 2018, the U.S. Geological Survey installed a streamgage at the most downstream location on the Blacks Fork, upstream from the convergence with Smiths Fork, to characterize the stream. The Blacks Fork above Smiths Fork, near Lyman, Wyoming, streamgage (U.S. Geological Survey identifier 09219200) was operated from April 4, 2018, through September 30, 2019, collecting continuous stream stage and specific-conductance data, from which continuous discharge, dissolved-solids concentrations, and dissolved-solids loads were calculated. Seven sites were selected on Blacks Fork and a tributary to describe a snapshot of the discharge and dissolved-solids concentration. These sites were sampled during July, August, and September 2018 and June, July, August, and September 2019.

Discharge at the Blacks Fork above Smiths Fork, near Lyman, Wyo., streamgage (09219200) from April through September was lower and less variable in 2018 than during the same period in 2019. The mean daily (mean of the daily means) discharge during those 6 months in 2018 (15.1 cubic feet per second $\left[\mathrm{ft}^{3} / \mathrm{s}\right]$ ) was about one-tenth of the discharge during the same period in $2019\left(152 \mathrm{ft}^{3} / \mathrm{s}\right)$. The cumulative monthly discharge during April through September in 2018 was 5,360 acre-feet and during the same period in 2019 was 54,700 acre-feet. These various metrics reflect the different climatic conditions during the water years, with conditions being warmer and drier than normal during water year 2018 (October 1, 2017, through September 30, 2018) and cooler and wetter than normal during water year 2019 (October 1, 2018, through September 30, 2019).

Continuous specific conductance data and the statistical relation between specific conductance and dissolvedsolids concentrations were used to calculate the daily mean dissolved-solids concentration. Dissolved solids often have an inverse relation to discharge, because typically higher discharges tend to have a diluting effect that lowers the dissolvedsolids concentrations. In general, when there was increased discharge in the Blacks Fork above Smiths Fork streamgage (09219200) there were lower dissolved-solids concentrations. However, the high dissolved-solids concentrations that are measured during high discharges indicate that the system has natural variability and the dissolved-solids concentrations are determined by more factors than just discharge. The mean daily dissolved-solids concentration during April through September 2018 was about 1.5 times higher in 2018 (1,630 milligrams per liter) than during the same 6 months in 2019 (1,090 milligrams per liter).

Dissolved-solids loads were calculated as the product of the discharge and dissolved-solids concentration. The daily mean dissolved-solids loads load at the Blacks Fork above Smiths Fork, near Lyman, Wyo., streamgage (09219200) during 2018 were typically lower than during 2019. The mean daily discharge during April through September 2018 was $15.1 \mathrm{ft}^{3} / \mathrm{s}$ and during the same period (April through September) in 2019 was $152 \mathrm{ft}^{3} / \mathrm{s}$ - about 10 times higher than in 2018. Therefore, although the daily mean dissolved-solids concentrations tended to be higher in 2018, the substantially higher daily mean discharges in 2019 had more of an effect on the dissolved-loads than did the daily mean dissolved-solids concentrations.

The cumulative dissolved-solids load at the Blacks Fork above Smiths Fork, near Lyman, Wyo., streamgage (09219200) during the 18-month study was 81,200 tons, with a mean daily load of 149 tons per day. During the 6-month period from April through September 2018, the cumulative dissolved-solids load at the streamgage was estimated to be 8,740 tons and, during the same 6 months in 2019, the cumulative dissolved-solids load was estimated to be 60,900 tons. During the fall and winter between the two periods, the cumulative dissolved-solids load was 11,600 tons.

Synoptic or "snapshot" sampling, where discharge measurements and surface-water samples are collected from several sites along a reach during a short period (typically within about 24 hours), was used to describe changes in the discharge and water quality of Blacks Fork at several sites during 1 or 2 days. A total of seven sites were visited during seven sampling events during 2018 and 2019. Discharge and dissolved-solids concentrations from samples collected during the synoptic sampling events were highly variable among sites during most synoptic sampling events and also highly variable at most sites among different sampling events. The two sites upstream from the tributary input from Threemile Creek had lower dissolved-solids concentrations than sites including and downstream from the tributary. Sites including and downstream from the tributary had similar values and variability of dissolved-solids loads, with the exception of the farthest downstream site at the Blacks Fork above Smiths Fork, near Lyman, Wyo., streamgage (09219200) that tended to have larger values and higher variability among synoptic sampling events. The mean instantaneous dissolved-solids 
load during the synoptic sampling events for the tributary and sites downstream (except for the most downstream site at the Blacks Fork above Smiths Fork, near Lyman, Wyo., streamgage [09219200]) was about 100 tons per day, and the mean instantaneous load at the streamgage during the synoptic sampling events was about 150 tons per day. The calculated 2018 dissolved-solids loads at the synoptic sampling sites were much less than 2019 loads, primarily because discharges were higher in 2019. Dissolved-solids concentrations were only slightly higher in 2018 than in 2019.

\section{References Cited}

Bradley, W.H., 1936, Geomorphology of the north flank of the Uinta Mountains: U.S. Geological Survey Professional Paper 185-I, p. 163-199.

Bureau of Reclamation, 2021, Reclamation Information Sharing Environment (RISE) - Time series query: accessed January 10, 2021, at https://data.usbr.gov/time-series/ output?id=575.19731001-20200930.4333.19731001$20200930 \& i \mathrm{t}=4333-575 \& l_{0}=411 \& \mathrm{v}=1$.

Carr, N.B., and Melcher, C.P., eds., 2017, Wyoming Basin Rapid Ecoregional Assessment (ver. 1.1, April 2017): U.S. Geological Survey Open-File Report 2015-1155, 896 p., accessed November 10, 2020, at https:/doi.org/10.3133/ ofr20151155.

Clark, M.L., and Davidson, S.L., 2009, Specific conductance and dissolved-solids characteristics for the Green River and Muddy Creek, Wyoming, water years 1999-2008: U.S. Geological Survey Scientific Investigations Report 2009-5068, 18 p., accessed March 28, 2020, at https://doi.org/10.3133/sir20095168.

Colorado River Basin Salinity Control Forum, 1975, Water quality standards for salinity, including numeric criteria and plan of implementation for salinity control - Colorado River System: Denver, Colo., Colorado River Basin Salinity Control Forum, variously paged, accessed February 14, 2020, at https://www.coloradoriversalinity.org/docs/ 1975\%20Review.pdf.

Colorado River Basin Salinity Control Forum, 2011, 2011 Review water quality standards for salinity - Colorado River System: Denver, Colo., Colorado River Basin Salinity Control Forum, 99 p. [Also available at https://www. coloradoriversalinity.org/docs/2011\%20REVIEWOctober.pdf.]

Fishman, J.F., and Friedman, L.C., eds., 1989, Methods for determination of inorganic substances in water and fluvial sediments: U.S. Geological Survey Techniques of WaterResources Investigations, book 5, chap. A1, 545 p. [Also available at https://doi.org/10.3133/twri05A1.]
Helsel, D.R., Hirsch, R.M., Ryberg, K.R., Archfield, S.A., and Gilroy, E.J., 2020, Statistical methods in water resources: U.S. Geological Survey Techniques and Methods, book 4, chap. A3, 458 p. [Also available at https://doi.org/ 10.3133/tm4a3.]

Hirsch, R.M., Moyer, D.L., and Archfield, S.A., 2010, Weighted regressions on time, discharge, and season (WRTDS), with an application to Chesapeake Bay river inputs: Journal of the American Water Resources Association, v. 46, p. 857-880. [Also available at https://onlinelibrary.wiley.com/doi/full/10.1111/j.17521688.2010.00482.x.]

Koenig, K.J., 1960, Bridger Formation in the Bridger Basin, Wyoming, in McGookey, D.P., and Miller, D.N., Jr., eds., Overthrust Belt of southwestern Wyoming and adjacent areas: Wyoming Geological Association Guidebook, 15th Annual Field Conference, 1960, p. 163-168.

Love, J.D., and Christiansen, A.C., 1985, Geologic map of Wyoming: U.S. Geological Survey, scale 1:500,000, 3 sheets., accessed November 13, 2020, at https://doi.org/ 10.3133/70046739.

Murphey, P.C., and Evanoff, E., 2007, Stratigraphy, fossil distribution, and depositional environments of the upper Bridger Formation (middle Eocene), southwestern Wyoming: Wyoming State Geological Survey Report of Investigations No. 57, $107 \mathrm{p}$.

Natural Resources Conservation Service, 2006, Salinity Control Plan, West Black's Salinity Control Project, Uinta County: Wyoming, Colorado River Salinity Control Program, $61 \mathrm{p}$.

NOAA Regional Climate Centers, 2020, Applied Climate Information System online database: Mountain View, Wyoming station website, accessed December 12, 2020, at http://scacis.rcc-acis.org/.

Nolan, K.M., and Shields, R.R., 2000, Measurement of stream discharge by wading: U.S. Geological Survey Water-Resources Investigations Report 00-4036, accessed November 11, 2020, at https://doi.org/10.3133/ wri20004036.

Rantz, S.E., and others, 1982a, Measurement and computation of streamflow-Volume 1, measurement of stage and discharge: U.S. Geological Survey Water-Supply Paper 2175, v. 1, 284 p., accessed March 5, 2020, at https://doi.org/ $10.3133 /$ wsp2175.

Rantz, S.E., and others, 1982b, Measurement and computation of streamflow-Volume 2, computation of discharge: U.S. Geological Survey Water-Supply Paper 2175, v. 2, 316 p., accessed March 5, 2020, at https://doi.org/ $10.3133 /$ wsp2175. 
Robinove, C.J., and Cummings, T.R., 1963, Ground-water resources and geology of the Lyman-Mountain View area Uinta County, Wyoming: U.S. Geological Survey WaterSupply Paper, v. 1669-E, p. E1-E43.

Runkel, R.L., Crawford, C.G., and Cohn, T.A., 2004, Load estimator (LOADEST) - A FORTRAN program for estimating constituent loads in streams and rivers: U.S. Geological Survey Techniques and Methods, book 4, chap. A5, 75 p., accessed November 28, 2020, at https://doi.org/ 10.3133/tm4A5.

Shope, C.L., and Gerner, S.J., 2014, Assessment of dissolvedsolids loading to the Colorado River in the Paradox Basin between the Dolores River and Gypsum Canyon, Utah: U.S. Geological Survey Scientific Investigations Report 2014-5031, 18 p., accessed November 5, 2020, at https://doi.org/10.3133/sir20145031.

Sunrise Engineering, 2013, Austin and Wall Canals, Level II Phase II study: report to Wyoming Water Development Commission August 2013, [variously paged].

Turnipseed, D.P., and Sauer, V.B., 2010, Discharge measurements at gaging stations: U.S. Geological Survey Techniques and Methods, book 3, chap. A8, 87 p. [Also available at https://doi.org/10.3133/tm3A8.]

U.S. Geological Survey, 1982, Geologic map of the Kings Peak 30’ x 60' quadrangle, Utah-Wyoming: U.S. Geological Survey metric topographic map, 1 sheet, scale 1:100,000.

U.S. Geological Survey, variously dated, National field manual for the collection of water-quality data: U.S. Geological Survey Techniques of Water-Resources Investigations, book 9, chaps. A1-A10, accessed November 2, 2020, at https://doi.org/10.3133/twri09.
U.S. Geological Survey, 2020a, USGS 09219200 Blacks Fork above Smiths Fork, near Lyman, WY, in USGS water data for the Nation: U.S. Geological Survey National Water Information System database, accessed November 3, 2020, at https://doi.org/10.5066/F7P55KJN. [Site information directly accessible at https://waterdata.usgs.gov/wy/nwis/ inventory/?site_no=09219200\&agency_cd=USGS.]

U.S. Geological Survey, 2020b, Water-year summary for site 09219200, in USGS water data for the Nation: U.S. Geological Survey National Water Information System database, accessed November 9, 2020, at https://doi.org/ 10.5066/F7P55KJN. [Site information directly accessible at https://waterdata.usgs.gov/wy/nwis/wys_rpt/?site_no= 09219200.]

U.S. Geological Survey, 2021a, USGS surface-water data for Wyoming: U.S. Geological Survey National Water Information System database, accessed February 14, 2021, at https://doi.org/10.5066/F7P55KJN or https://waterdata. usgs.gov/wy/nwis/sw.

U.S. Geological Survey, 2021b, Water-year summary for site USGS 09219200: U.S. Geological Survey National Water Information System database, accessed February 22, 2021, at https://doi.org/10.5066/F7P55KJN. [Site information directly accessible at https://waterdata.usgs.gov/wy/nwis/ wys_rpt/?site_no=09219200\&agency_cd=USGS.]

Western Regional Climate Center, 2020, Wyoming climate summaries, Mountain View, Wyoming: Reno, Desert Research Institute, Western Regional Climate Center, digital data, accessed December 3, 2020, at https://wrcc.dri.edu/ cgi-bin/cliMAIN.pl?wy6555.

Wyoming State Engineer's Office, 2021, Real-time SEO water data: accessed February 20, 2021, at http://seoflow. wyo.gov/. 


\section{Appendix 1. Calculation of Relative Percent Differences in Dissolved-Solids Concentrations of Replicate Samples}

Replicate samples were collected and processed in the same manner as the environmental sample and were used to determine the repeatability of the sampling methods and laboratory analyses of dissolved-solids concentrations. Relative percent differences were calculated using the equation:

$$
R P D=\text { absolute values }(E S-R S /((E S+R S) / 2)) \times 100
$$

where

ES is the dissolved-solids concentration, in milligrams per liter, of the environmental sample; and

$R S \quad$ is the dissolved-solids concentration, in milligrams per liter, of the replicate sample.

The dissolved-solids concentrations for the environmental sample, the replicate sample, and the relative percent difference are shown in table 1.1 .

Table 1.1. Dissolved-solids concentrations of environmental sample and replicate sample, and relative percent difference for four samples collected at the Blacks Fork above Smiths Fork near, Lyman, Wyoming, streamgage (09219200).

[mg/L, milligram per liter]

\begin{tabular}{lccc}
\hline Sample date & $\begin{array}{c}\text { Dissolved-solids concentration, } \\
\text { environmental sample } \\
\text { (mg/L) }\end{array}$ & $\begin{array}{c}\text { Dissolved-solids concentration, } \\
\text { replicate sample } \\
\text { (mg/L) }\end{array}$ & Relative percent difference \\
\hline $06 / 14 / 2018$ & 1,096 & 1,122 & 2.36 \\
$07 / 09 / 2019$ & 1,130 & 1,140 & 0.88 \\
$08 / 14 / 2019$ & 873 & 840 & 3.80 \\
$09 / 11 / 2019$ & 1,081 & 1,110 & 2.64 \\
\hline
\end{tabular}


For more information about this publication, contact: Director, USGS Wyoming-Montana Water Science Center 521 Progress Circle, Suite 6

Cheyenne, WY 82007

307-778-2931

For additional information, visit: https://www.usgs.gov/centers/wymt-water/

Publishing support provided by the

Rolla and Lafayette Publishing Service Centers 


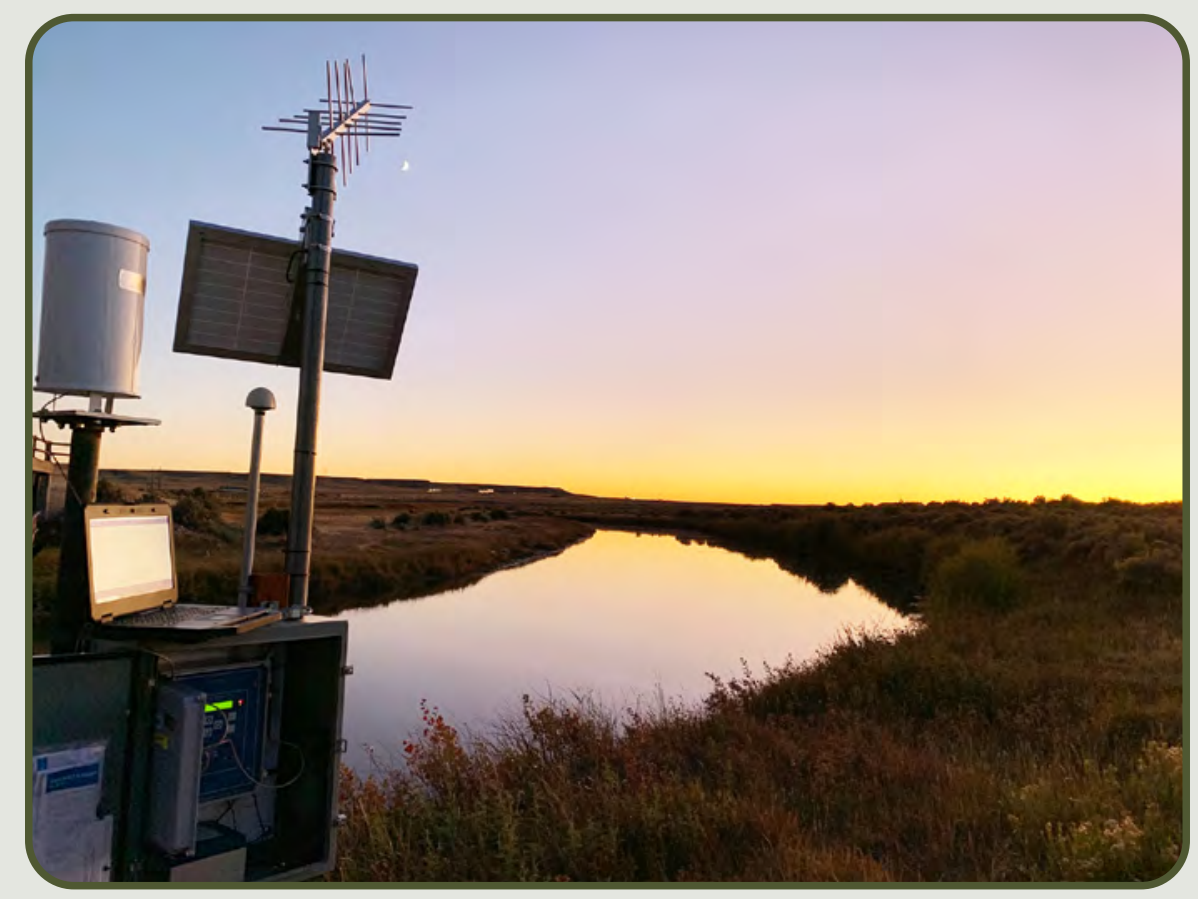

